\title{
Recent Progress in the Development of Poly(lactic-co-glycolic acid)-Based Nanostructures for Cancer Imaging and Therapy
}

\author{
Ki-Taek Kim ${ }^{1,+}{ }^{\text {, Jae-Young Lee }}{ }^{2,+}$, Dae-Duk Kim ${ }^{3}$, In-Soo Yoon ${ }^{4, *(1)}$ and Hyun-Jong Cho ${ }^{5, *(\mathbb{D})}$ \\ 1 College of Pharmacy and Natural Medicine Research Institute, Mokpo National University, Muan-gun, \\ Jeonnam 58554, Korea; ktkim0628@mokpo.ac.kr \\ 2 College of Pharmacy, Chungnam National University, Daejeon 34134, Korea; jaeyoung@cnu.ac.kr \\ 3 College of Pharmacy and Research Institute of Pharmaceutical Sciences, Seoul National University, \\ Seoul 08826, Korea; ddkim@snu.ac.kr \\ 4 Department of Manufacturing Pharmacy, College of Pharmacy, Pusan National University, Busan 46241, \\ Korea \\ 5 College of Pharmacy, Kangwon National University, Chuncheon 24341, Korea \\ * Correspondence: insoo.yoon@pusan.ac.kr (I.-S.Y.); hjcho@kangwon.ac.kr (H.-J.C.) \\ + These authors are equally contributed to this work.
}

Received: 14 May 2019; Accepted: 11 June 2019; Published: 14 June 2019

check for updates

\begin{abstract}
Diverse nanosystems for use in cancer imaging and therapy have been designed and their clinical applications have been assessed. Among a variety of materials available to fabricate nanosystems, poly(lactic-co-glycolic acid) (PLGA) has been widely used due to its biocompatibility and biodegradability. In order to provide tumor-targeting and diagnostic properties, PLGA or PLGA nanoparticles (NPs) can be modified with other functional materials. Hydrophobic or hydrophilic therapeutic cargos can be placed in the internal space or adsorbed onto the surface of PLGA NPs. Protocols for the fabrication of PLGA-based NPs for cancer imaging and therapy are already well established. Moreover, the biocompatibility and biodegradability of PLGA may elevate its feasibility for clinical application in injection formulations. Size-controlled NP's properties and ligand-receptor interactions may provide passive and active tumor-targeting abilities, respectively, after intravenous administration. Additionally, the introduction of several imaging modalities to PLGA-based NPs can enable drug delivery guided by in vivo imaging. Versatile platform technology of PLGA-based NPs can be applied to the delivery of small chemicals, peptides, proteins, and nucleic acids for use in cancer therapy. This review describes recent findings and insights into the development of tumor-targeted PLGA-based NPs for use of cancer imaging and therapy.
\end{abstract}

Keywords: cancer; diagnosis; nanoparticle; PLGA; targeting; therapy

\section{Introduction}

There has been much progress in the development of nanomedicines for use cancer imaging and therapy [1-20]. To increase the potential for clinical application, nanomedicines with increased precision and safety have recently been designed and evaluated. Following intravenous administration, particles with a certain size range can localize to the tumor region through an "enhanced permeability and retention (EPR) effect" [21-23]. Molecules or particles with a size of $>40 \mathrm{kDa}$ (renal clearance threshold) may be present in the systemic circulation for a prolonged period [22,23]. Leaky tumor vasculature and insufficient lymphatic drainage of tumor tissue can increase the permeability and accumulation of particles [24]. Although the EPR effect has been proved in many animal studies, its usefulness for clinical application is still controversial [21]. The pathophysiological states are different according to 
the animal species (rodent versus human), tumor types originated from same source, and primary versus metastatic tumors in the same patient [21]. Consideration of the heterogeneity of EPR effect is necessary for the successful translation of nanomedicines to the clinical situation [21]. As drug delivery via EPR does not usually occur in normal tissues, it can be used as a passive tumor-targeting strategy [25]. However, the heterogeneity of tumor tissue, including highly hypovascular areas and necrotic tissues, frequently observed in large tumors may limit the efficiency of particle delivery. In addition to various factors that modulate the EFR effect [26] (e.g., bradykinin, nitric oxide derivatives, prostaglandins, angiotensin-converting enzyme inhibitors, and vascular endothelial growth factor [VEGF]), ligand-receptor interactions have been introduced as an active tumor-targeting strategy [27]. Ligands can be selected to bind receptors that are overexpressed in cancer cells compared with normal cells [27]. Receptors in tumor cells (e.g., transferrin [Tf] receptor, folate receptor, lectins, and epidermal growth factor receptor [EGFR]) or on the tumoral endothelium (e.g., VEGF receptors, $\alpha_{v} \beta_{3}$ integrin, vascular cell adhesion molecule-1 [VCAM-1] and matrix metalloproteinases [MMPs]) can be targets of ligand-tethered nanosystems [27]. Recently, internal (e.g., pH, enzyme, and redox state) and external (e.g., temperature, magnetism, and ultrasound) stimuli-sensitive smart nanosystems have been designed to provide more sophisticated drug-release patterns and selective uptake in cancer cells [27]. Additive properties, such as tumor penetration, the induction of apoptosis, and inhibition of metastasis, have been built in nanosystems for use in cancer imaging and therapy [28-38].

To reduce toxicity in the development of tumor-targeted nanomedicines, biocompatibility and biodegradability are considered principal issues in the selection of materials for nanosystems. Various types of synthetic polymers (e.g., poly(lactic-co-glycolic acid) [PLGA]), natural polymers (e.g., chitosan [CS], chondroitin sulfate [CD], and hyaluronic acid [HA]), lipids (e.g., phospholipid and cholesterol), nucleic acids (e.g., DNA), peptides/proteins (e.g., albumin and lysozyme), and inorganic materials (e.g., gold, iron, silver, and zinc) have been used to prepare nanoformulations for cancer therapy [39-58]. Among these diverse materials, PLGA is a favored substance for the fabrication of nanoparticles (NPs) aimed at drug delivery [59-61]. PLGA can be degraded into lactic acid (LA) and glycolic acid (GA), which can enter metabolic pathways. Therefore, it can be safely applied to the preparation of injection formulations. PLGA has received approval from the United States Food and Drug Administration and the European Medicine Agency for its application in injectable formulations [62]. It can be chemically modified to give biofunctionality (i.e., tumor-targeting capability), and the outer surface of PLGA-based NPs can be transformed to provide a prolonged circulation time and tumor targetability [63-66]. Small chemicals, peptides, proteins, and nucleic acids with diverse physicochemical properties can be entrapped in PLGA or PLGA derivative-based NPs or adsorbed onto the outer surface of NPs [61,67-70]. Convenient modification and reliability in the fabrication of NPs, as well as their favorable biosafety, may elevate the feasibility of applying PLGA-based NPs in the clinic.

Several articles have reviewed the application of PLGA nanomedicines to drug delivery [59,61,62, 67]. Herein, we introduce recent progress in the development and evaluation of PLGA-based NPs for cancer imaging and therapy. Information regarding the preparation, cellular uptake and distribution, in vivo tumor targeting, in vivo cancer therapy, and in vivo pharmacokinetics of PLGA-based NPs will be provided.

\section{Preparation and Modification of PLGA-Based NPs}

\subsection{Preparation of PLGA NPS}

The fabrication method of PLGA NPs may affect their physicochemical properties, such as particle size, particle size distribution, particle shape, drug encapsulation efficiency, and particle stability [71]. The most common methods for the preparation of PLGA NPs, such as emulsification, nanoprecipitation, spray-drying, and microfluidics, are described in following sections. 


\subsubsection{Emulsification-Evaporation Method}

Emulsification is the most frequently used method. This method can be subdivided based on the emulsion (single; e.g., oil in water [O/W] emulsion and double or multiple; e.g., water in oil in water [W/O/W] emulsion) and acquisition of the NPs (i.e., solvent evaporation and dialysis). PLGA polymers and hydrophobic drugs can be dissolved in water-immiscible organic solvents, such as chloroform or dichloromethane, followed by addition to the aqueous phase containing a surfactant such as poly(vinyl alcohol) (PVA) to obtain an O/W emulsion. This emulsification can be prepared using a homogenizer or ultrasonic probe, which can provide high shear energy. Then, the organic solvent can be evaporated with simple stirring, under a gentle nitrogen gas stream, or in a vacuum state. The hardened NPs can be obtained by centrifugation, washed to remove remaining surfactants, and lyophilized for further storage. The organic solvent in the oil phase of emulsion systems can also be diffused by dialysis against a large amount of water. Solidified particles containing PLGA polymer and drugs may be precipitated and acquired [60,62].

The double or multiple emulsion method can be used to encapsulate further hydrophilic drugs. An aqueous solution containing hydrophilic drugs is added to the PLGA-dissolved organic phase under vigorous stirring to obtain a W/O emulsion. This emulsion is added to the second aqueous solution containing a surfactant under high-shear energy to form a W/O/W emulsion. Then, the hardened NPs can be obtained by solvent evaporation [72].

The emulsification method can be used to encapsulate both hydrophobic and hydrophilic drugs. Furthermore, it can be used to prepare particles, varying from nano to micron size by adjusting the stirring speed and input rate [71]. Nonetheless, there are some problems with this method, such as the requirement for heat or a vacuum for solvent evaporation and the imperfect elimination of stabilizer [72]. Recently, membrane extrusion has been used to prepare NPs with a narrow size distribution after the emulsification process. Membrane extrusion is performed using a polycarbonate membrane under high pressure [60].

\subsubsection{Nanoprecipitation Method}

PLGA and hydrophobic drugs can be dissolved in a water-miscible solvent such as dimethyl sulfoxide (DMSO), acetone, and ethanol. This organic solution is usually injected into an aqueous solution containing surfactant at a controlled speed with an auto-injector. NPs can be formed by the rapid diffusion of polymers and drugs out of organic phase. Then, they can be obtained by solvent elimination [73].

Nanoprecipitation is used to load hydrophobic drugs into the NPs via a one-step procedure. This method can be useful to prepare PLGA NPs with a $<100 \mathrm{~nm}$ particle size, which can be determined by the polymer concentration [60]. The advantages of this method include its easy scale-up, low energy requirement, high reproducibility, and single step process. The limitations include the low encapsulation efficiency of the hydrophilic drug and particle size variation, which is dependent on the mixing process [72].

\subsubsection{Spray-Drying Method}

The spray-drying method is a rapid process that can be used to encapsulate both hydrophobic and hydrophilic drugs. Aqueous solution containing hydrophilic drugs may be added to the PLGA-dissolved organic phase under vigorous stirring to obtain the W/O emulsion, and can be used to make multiple emulsion. Particles are obtained by spraying W/O emulsion or multiple emulsion with a stream of heated air [74]. However, the main limitation of this method is the adhesion of particles to the walls and cyclone part of the spray dryer, resulting in low productivity [68]. 


\subsubsection{Microfluidics Method}

The continuous-phase flow microfluidic system, including a flow-focusing system and co-flowing system, can be used to prepare nano-sized PLGA particles by forming single emulsions. In the flow-focusing system, the dispersed phase flows through a narrow capillary and the continuous phase flows from the two side channels with the vertical direction of the dispersed phase. In the co-flowing system, the dispersed phase flows inside the capillary and the continuous phase flows outside the capillary in the same direction [60].

The microfluidic method has several advantages for preparing PLGA NPs, such as a narrow size distribution, high reproducibility, and the prevention of an initial burst release. Moreover, the microfluidic system can be used to prepare various surface-modified PLGA NPs, such as PEGylated NPs and NPs carrying targeting moieties [72]. However, it also has limitations, including limited production scale (and scale-up), and problems associated with microchannel clogging and fouling [72].

\subsection{Surface Modification of PLGA NPs for Tumor Targeting}

\subsubsection{Physicochemical and Biological Properties of PLGA}

PLGA is a copolymer composed of LA and GA and those two units are linked via an ester bond. Therefore, PLGA can be degraded into LA and GA by hydrolysis in the body and can join in metabolic pathways $[67,75]$. The degradation of PLGA NPs may be influenced by the molecular weight (MW), molar ratio between LA and GA, crystalline degree, glass transition temperature, and the type of end cap (acid versus ester) [62,67]. Poly(lactic acid) (PLA) is more hydrophobic than poly(glycolic acid) (PGA); thus, a PLGA copolymer with a higher ratio of LA/GA may be degraded more slowly [62]. Additionally, PLGA with an ester end cap may have higher resistance to hydrolysis compared with PLGA with an acid end cap [62]. This biocompatibility and biodegradability can increase the feasibility of using PLGA NPs in clinical applications. By modulating the polymerization process, various types of PLGA in terms of MW, LA:GA ratio, end cap, and chirality, can be prepared. Those properties can affect polymer degradation, drug release from NPs, cellular uptake, and the in vivo fate of NPs [59-62,65-69]. Furthermore, several block or grafted copolymer types (e.g., linear, branched, and star-shaped) based on PLGA can be synthesized with CS, HA, poly(caprolactone) (PCL), poly(ethylene glycol) (PEG), polyethylenimine (PEI), poly-L-lysine (PLL), poly(styrene), and PVA [59,62,76-78]. Amphiphilic copolymers (e.g., PEG-PLGA and PLGA-PEG-PLGA) can form a micellar structure following dispersal in an aqueous environment, and present different particle characteristics $[79,80]$. In addition, reactive units (e.g., amine, maleimide, $N$-hydroxysuccinimide, and vinyl) can be attached to the terminal end of a PLGA copolymer. These functional groups can participate in further modifications with tumor-targeting ligands or drug cargos. These structural changes can modulate the physicochemical and biological properties of PLGA-based NPs $[62,67,69]$.

\subsubsection{Surface Engineering of PLGA-Based NPs}

For active tumor-targeting strategies (i.e., ligand-receptor interaction) together with a passive tumor-targeting approach (i.e., EPR effect), the outer surface of PLGA-based NPs has been engineered with various functional groups. Two methods can be used to prepare surface-engineered PLGA NPs; 1 ) After synthesizing PLGA derivatives (linked to functional groups), they can then be used to fabricate NPs. 2) After fabricating PLGA NPs, the exposed functional groups (i.e., carboxylic acid and hydroxyl groups) of PLGA are chemically linked to targeting moieties, or the outer surface of PLGA NPs are coated with functional materials.

For prolonged circulation in the blood, hydrophilic molecules such as PEG, poloxamers, and Tween 80 are usually conjugated on the surface of PLGA NPs. These hydrophilic molecules on the NPs can infer stealth properties, leading to the evasion of phagocytic uptake by the reticuloendothelial system (RES), and a prolonged time in the systemic circulation [81]. Furthermore, PLGA NPs conjugated or 
coated with positively-charged molecules such as CS can be taken into the tumor cells more easily via adsorptive-mediated transcytosis [82].

Active targeting for tumor-specific delivery can be achieved by introducing targeting moieties to the surface of NPs, which are specifically recognized by receptors on the tumor cells or tumor vasculature, resulting in the increased penetration of tumor cells via receptor-mediated endocytosis [83]. The receptors or surface-bound antigens may be expressed exclusively or overexpressed on the tumor cells compared with normal cells. Various targeting moieties such as folic acid (FA), Tf, biotin, HA, peptides, aptamers, and antibodies (Abs) have been used on the surface of PLGA NPs to actively target tumor microenvironments (Table 1). However, the expression of receptors on the tumor cell or vasculature can be altered and alternative receptors can be upregulated [72]. Recently, NPs carrying multiple (e.g., dual or triple) ligands have been investigated to maximize tumor-targeting efficiency.

The development of multi-functional PLGA NPs modified with cell-penetration peptides, Pluronic ${ }^{\circledR}$ P85 (an inhibitor for drug efflux pump), or PEG are promising strategies for use in cancer therapy [84]. These PLGA NPs can passively target delivery to tumors via the EPR effect, and actively target delivery to tumors based on ligand-receptor interactions, and overcome drug resistance with inhibitors of efflux pumps, finally improving anti-tumor efficacies and reducing systemic toxicity in normal tissues and organs $[85,86]$. Surface-engineered PLGA NPs for passive and active tumor targeting are illustrated and summarized in Figure 1 and Table 1, respectively.

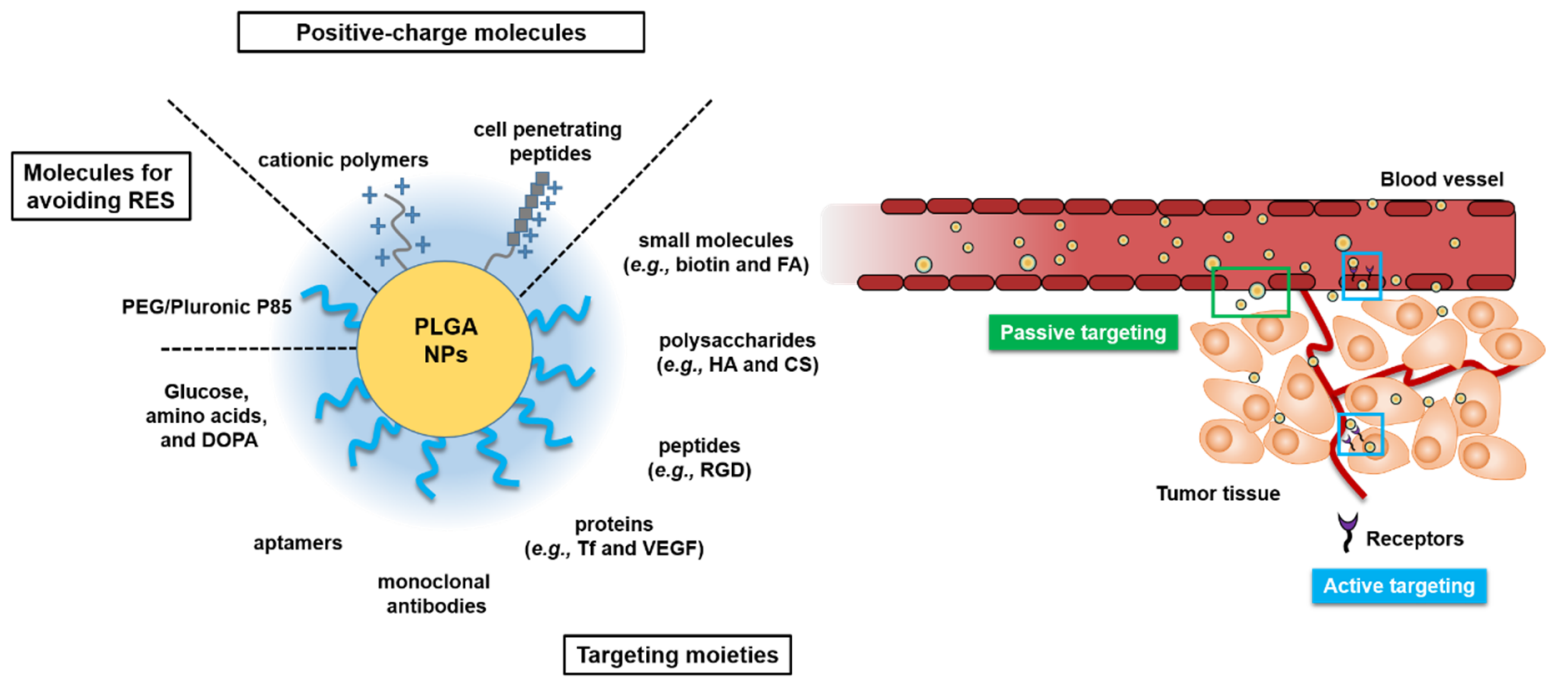

Figure 1. Various surface-engineered poly(lactic-co-glycolic acid) (PLGA) nanoparticles (NPs) for passive or active tumor targeting. Arg-Gly-Asp (RGD); chitosan (CS); dopamine (DOPA); folic acid (FA); hyaluronic acid (HA); poly(ethylene glycol) (PEG); reticuloendothelial system (RES); transferrin (Tf); vascular endothelial growth factor (VEGF). 
Table 1. Surface modification methods of PLGA NPs for tumor targeting.

\begin{tabular}{|c|c|c|c|c|}
\hline Formulation & Anticancer Agent & Target (Cell Line) & Surface Modification Method & Ref. \\
\hline mPEG-PLGA NPs & Mitramycin & $\begin{array}{l}\text { Pancreatic carcinoma } \\
\text { (BxPC-3 and MIA } \\
\text { Paca- } 2 \text { cells) }\end{array}$ & $\begin{array}{l}\text { Mitramycin was loaded onto mPEG-PLGA NPs } \\
\text { by the single-emulsion solvent evaporation } \\
\text { method using poloxamer } 188 \text { as a stabilizer }\end{array}$ & [87] \\
\hline $\begin{array}{c}\text { CS-modified PLGA } \\
\text { NPs }\end{array}$ & PTX & $\begin{array}{c}\text { Breast cancer } \\
\text { (MDA-MB- } 231 \text { cells) }\end{array}$ & $\begin{array}{l}\text { PTX-loaded PLGA NPs were prepared by the } \\
\text { nanoprecipitation method using a high-gravity } \\
\text { rotating packed bed. Then, PLGA NPs were } \\
\text { modified with CS through electrostatic } \\
\text { adherence }\end{array}$ & [88] \\
\hline $\begin{array}{l}\text { Pluronic }{ }^{\circledR} \text { P85 or } \\
\text { Tf-modified PLGA } \\
\text { NPs }\end{array}$ & PTX & Glioma (C6 cells) & $\begin{array}{c}\text { PTX-loaded PLGA NPs were prepared by the } \\
\text { nanoprecipitation method. PLGA NPs were } \\
\text { coated with Pluronic }{ }^{\circledR} \text { P85 or conjugated with } \\
\text { Tf }\end{array}$ & [89] \\
\hline $\begin{array}{l}\mathrm{C}_{24} \text {-LMWP } \\
\text { peptide-modified } \\
\text { PLGA NPs }\end{array}$ & DOX & $\begin{array}{l}\text { Drug-resistant lung } \\
\text { cancer (A549/T cells) } \\
\text { and drug-resistant } \\
\text { breast cancer } \\
\text { (MCF-7/ADR cells) }\end{array}$ & $\begin{array}{c}\text { Desalted DOX-loaded PLGA NPs were } \\
\text { prepared by the nanoprecipitation method. } \\
\text { Then, a } \mathrm{C}_{24} \text {-LMWP hybrid peptide was } \\
\text { introduced to PLGA NPs by electrostatic } \\
\text { interaction }\end{array}$ & [90] \\
\hline $\begin{array}{l}\text { HA-PEG- PLGA or } \\
\text { CD-PEG-PLGA } \\
\text { NPs }\end{array}$ & pDNA lipoplex & $\begin{array}{c}\text { Glioblastoma (U87 } \\
\text { cells) }\end{array}$ & $\begin{array}{l}\text { HA or CD was conjugated to PLGA-PEG-NH} \\
\text { using a reducing agent and a catalyst. } \\
\text { HA-PEG-PLGA or CD-PEG-PLGA NPs were } \\
\text { prepared by the dialysis method }\end{array}$ & [91] \\
\hline $\begin{array}{l}\text { PLGA-PEG-biotin } \\
\text { NPs }\end{array}$ & $\begin{array}{l}\text { SN-38 (active } \\
\text { metabolite of } \\
\text { irinotecan) }\end{array}$ & $\begin{array}{l}\text { Breast cancer }(4 \mathrm{~T} 1 \\
\text { cells) }\end{array}$ & $\begin{array}{l}\text { NHS-Biotin and } \mathrm{H}_{2} \mathrm{~N}-\mathrm{PEG}-\mathrm{NH}_{2} \text { were } \\
\text { conjugated. Then, PEG-biotin was conjugated } \\
\text { to PLGA-NHS to synthesize PLGA-PEG-biotin. } \\
\text { PLGA-PEG-biotin NPs were prepared by the } \\
\text { modified emulsification solvent evaporation } \\
\text { method }\end{array}$ & [92] \\
\hline $\begin{array}{c}\text { PLGA-PLL-PEG-Tf } \\
\text { NPs }\end{array}$ & DNR & Leukemia (K562 cells) & $\begin{array}{l}\text { DNR-loaded PLGA-PLL-PEG NPs were } \\
\text { prepared by the modified double-emulsion } \\
\text { solvent evaporation/diffusion method. Tf was } \\
\text { conjugated to the surface of NPs with CDI }\end{array}$ & [93] \\
\hline $\begin{array}{l}\text { Anti-EGFR } \\
\text { mAb-PLGA-PEG } \\
\text { NPs }\end{array}$ & PTX & $\begin{array}{l}\text { Triple-negative breast } \\
\text { cancer (MDA-MB- } 468 \\
\text { cells) }\end{array}$ & $\begin{array}{c}\text { PTX-loaded PLGA-PEG NPs were prepared by } \\
\text { the nanoprecipitation method. The anti-EGFR } \\
\text { mAb was anchored on the surface of NPs by } \\
\text { crosslinking with MBS }\end{array}$ & [94] \\
\hline $\begin{array}{l}\text { CS-RGD-modified } \\
\text { PLGA NPs }\end{array}$ & PTX or CDDP & $\begin{array}{l}\text { Lung cancer (H1299 } \\
\text { and A549 cells) }\end{array}$ & $\begin{array}{c}\text { Drug-loaded PLGA NPs were prepared by the } \\
\text { emulsification solvent evaporation (PTX) or } \\
\text { double emulsion (CDDP) method. CS-RGD } \\
\text { was synthesized by conjugating the GRGDSP } \\
\text { peptide to chitosan via maleimide-PEG-NHS. } \\
\text { CS-RGD was physically adsorbed onto the } \\
\text { PLGA NPs }\end{array}$ & [95] \\
\hline Glucose-PLGA & DTX & $\begin{array}{l}\text { Human laryngeal } \\
\text { carcinoma (Hep-2 } \\
\text { cells) }\end{array}$ & $\begin{array}{l}\text { DTX-loaded glucose-PLGA NPs were prepared } \\
\text { by the single-emulsion solvent evaporation } \\
\text { method. }\end{array}$ & [70] \\
\hline $\begin{array}{l}\text { CD133 aptamer- } \\
\text { PEG-PLGA }\end{array}$ & Salinomycin & $\begin{array}{l}\text { CD133-positive } \\
\text { osteosarcoma (Saos- } 2 \\
\text { cells) and cancer stem } \\
\text { cells }\end{array}$ & $\begin{array}{l}\text { Salinomycin was loaded into } \\
\text { PLGA-PEG-COOH NPs by the single-emulsion } \\
\text { solvent evaporation method. CD133 aptamers } \\
\text { were conjugated to PLGA-PEG-COOH NPs by } \\
\text { EDC/NHS coupling. }\end{array}$ & [96] \\
\hline
\end{tabular}

Arg-Gly-Asp (RGD); chitosan (CS); chondroitin sulfate (CD); cis-diamine platinum (CDDP); daunorubicin (DNR); dicyclohexylcarbodiimide (DCC); docetaxel (DTX); doxorubicin (DOX); epidermal growth factor receptor (EGFR); 1-Ethyl-3-(3-dimethylaminopropyl) carbodiimide (EDC); hyaluronic acid (HA); low-molecular-weight protamine (LMWP); methoxypolyethylene glycol (mPEG); $m$-maleimidobenzoyl- $N$-hydroxysuccinimide (MBS); monoclonal antibody (mAb); $N$-hydroxysuccinimide (NHS); $N, N$-carbonyldiimidazole (CDI); paclitaxel (PTX); polyethylene glycol (PEG); poly(lactic-co-glycolic acid) (PLGA); poly-L-lysine (PLL); transferrin (Tf).

\section{Uptake of PLGA NPs into Cancer Cells}

The uptake of surface-engineered PLGA NPs into tumor cells can be described through several endocytosis mechanisms, such as receptor-, carrier-, and adsorption-mediated endocytosis (Figure 2). Increased cellular uptake of NPs can be observed using those endocytosis mechanisms, and thereby 
regarded as tumor-specific drug delivery strategies through passive or active targeting. Particle size, particle shape, the surface charge of particles, hydrophilicity/hydrophobicity of particles, elasticity of particles, and cell type can affect and determine the endocytosis pathway and efficiency [46,97-101]. Particles with 10-100 nm are reported to be necessary for entering the endocytic vesicles and smaller particles are known to be beneficial for their rapid cellular entry [100]. In addition, polydispersity and surface charge of particles may affect the cellular entry [100].

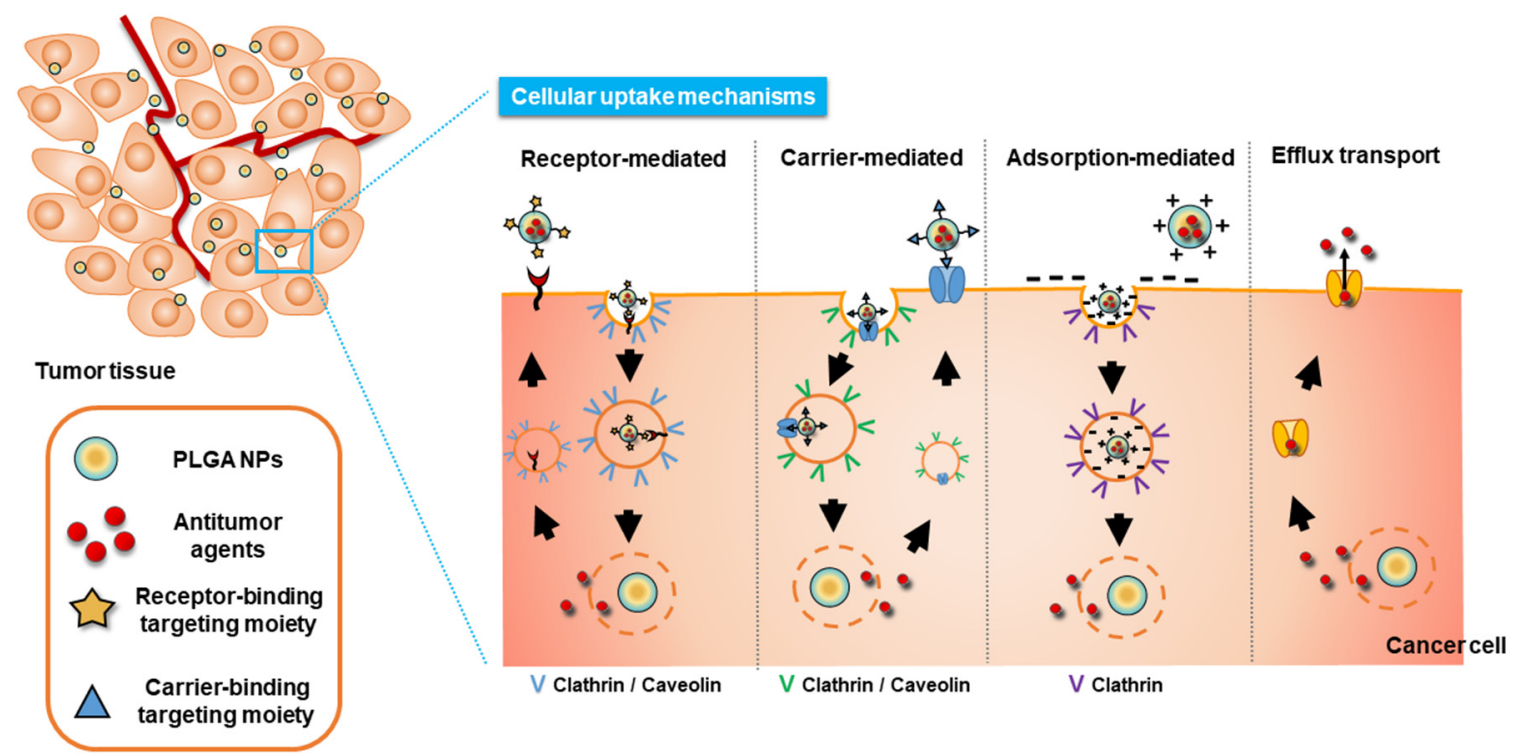

Figure 2. Cellular uptake mechanisms of surface-modified PLGA NPs.

\subsection{Receptor-Mediated Endocytosis}

Most NPs carrying anti-tumor agents, including PLGA NPs, can be internalized by endocytosis into the tumor cells. In receptor-mediated endocytosis, the NPs can be efficiently internalized into cells by the specific binding of targeting moieties anchored on the PLGA NPs and the corresponding receptors expressed on the tumor cell membrane or tumor vasculatures [102]. These specific ligand-receptor complexes include the biotin-biotin receptor, HA-CD44 receptor, anti-epidermal growth factor (EGF) antibody (Ab)-EGF receptor (EGFR), FA-folate receptor, Arg-Gly-Asp (RGD)-based peptide-integrin $\alpha_{\mathrm{v}} \beta_{3}$, and Tf-Tf receptor (Table 1 ).

Clathrin and caveolin are endogenous molecules that exist in the cytosol and function in receptor-mediated endocytosis. When NPs conjugated to targeting moieties interact with the receptor, each clathrin or caveolin molecule migrates from the cytosol to the cell membrane, encompasses the ligand-receptor complexes, and contributes to the production of clathrin-coated vesicles or caveosomes containing the complexes $[97,98]$. Clathrin-dependent endocytosis is a representative route of entry into mammalian cells [100]. In clathrin-dependent endocytosis, coated clathrin may be peeled off prior to fusion with early endosomes and NP will reach lysosomes via the endo-lysosomal route [97]. Conversely, in caveolin-dependent endocytosis, NPs can be internalized as a form of caveosome, which can avoid fusion with lysosomes and prevent lysosomal degradation $[97,103]$.

\subsection{Carrier-Mediated Endocytosis}

Some hydrophilic molecules, such as amino acids, peptides, monoamines, and glucose, which can be used as building blocks, neurotransmitters, and energy sources for cells are usually recognized selectively and transported actively via interaction with carrier proteins expressed on the cell membrane [104]. Tumor cells require high levels of energy and building blocks for their abnormal rapid growth, and thereby overexpress those carrier proteins, including hexose carriers and amino acid carriers. Thus, glucose can be used as a promising targeting moiety for the tumor-specific delivery 
of PLGA NPs. Glucose-included PLGA NPs can be specifically bound to glucose transporters such as GLUT-1 and GLUT-3 or sodium-glucose linked transporter (SGLT) -1 and -2 on certain tumor cells, followed by internalization into cells via carrier-mediated endocytosis [70].

For the treatment of brain tumors such as glioblastoma, therapeutic molecules should cross the blood-to-brain barrier (BBB), which is the most impermeable barrier in the human body [105]. Fortunately, for the purpose of transporting neurotransmitters (i.e., choline and L-dopa) and energy sources (i.e., glucose) into the brain, specific carriers, including choline transporter, L-system large neutral amino acid transporter, GLUT, and SGLT are present on the BBB $[70,106]$. Therefore, NPs loaded with anti-tumor agents for brain tumor-specific delivery could be modified with targeting moieties, which can be bound to those carriers on the BBB and receptors (i.e., CD44 receptor, folate receptor, and Tf receptor) on the tumor cells $[27,51,89,91]$.

\subsection{Adsorption-Mediated Endocytosis}

As the surface of cell membranes at physiological $\mathrm{pH}$ carries a slight negative charge, electrostatic interactions between cationic NPs and tumor cell membranes can promote particle adsorption to the tumor cells [107]. Non-functionalized PLGA NPs have a negative surface charge due to the structure of PLGA polymer, resulting in lower penetration into the tumor cells due to the electrostatic repulsion. Therefore, NPs functionalized with a cationic polymer such as CS and cell-penetrating peptides (CPPs) (e.g., low-molecular-weight protamine [LMWP], transactivator of transcription [TAT], and penetratin) can easily penetrate tumor cells via adsorption-mediated endocytosis [90,95,108]. Although there are some exceptions, positively charged NPs may be dominantly internalized via a clathrin-mediated pathway [100]. For example, CS-coated PLGA NPs were found to be internalized via both macropinocytosis and clathrin-mediated endocytosis, while the uptake PLGA NPs involved caveolin-mediated endocytosis in MDCK cells [108]. The positively charged surface of NPs may be associated with some issues, such as reduced circulation time due to the enhanced opsonization and recognition by the RES. Recent progress regarding particle properties-dependent endocytosis types is summarized in Table 2.

Table 2. Type of endocytosis depending on the particle properties of PLGA-based NPs.

\begin{tabular}{cccc}
\hline Surface Functionalities & Mean Diameter (nm) & Type of Endocytosis & Ref. \\
\hline AS1411 aptamer & 128 & $\begin{array}{c}\text { Receptor (nucleotin)-mediated } \\
\text { endocytosis }\end{array}$ & {$[109]$} \\
\hline CD44 antibodies & 140 & Receptor (CD44)-mediated endocytosis & {$[110]$} \\
\hline L-carnitine & 189 & Carrier (OCTN2)-mediated endocytosis & {$[111]$} \\
\hline $\begin{array}{c}\text { Glutamate- } \\
\text { polyoxyethylene stearate }\end{array}$ & $152-181$ & Carrier (LAT1)-mediated endocytosis & {$[112]$} \\
\hline CS & $140-173$ & Adsorption-mediated endocytosis & {$[88]$} \\
\hline PEG-HIV-TAT & $97-176$ & Adsorption-mediated endocytosis & {$[113]$} \\
\hline Arginine-rich peptide & 156 & Adsorption-mediated endocytosis & {$[114]$} \\
\hline
\end{tabular}

Organic cation/carnitine transporter 2 (OCTN2); large amino acid transporter 1 (LAT1); chitosan (CS); polyethylene glycol (PEG); human immunodeficiency virus (HIV); transactivator of transcription (TAT).

\section{Visualization of Tumor Targeting by In Vivo Imaging}

\subsection{Design of NPs with Imaging Modalities}

The tumor targeting ability of PLGA-based NPs can be demonstrated using in vivo imaging techniques. To monitor the in vivo fate of NPs, a corresponding imaging modality should be introduced to NPs (Figure 3). Imaging agents can be attached to the PLGA backbone (prior to NP fabrication) or to the outer surface of NPs (after NP fabrication) $[59,115]$. As commercial PLGA products possess a 
carboxylic acid or ester end group, they can be used to generate covalent bonding with the functional groups of imaging modalities [59]. For instance, amine or hydroxyl groups in the imaging agent can directly form an amide or ester linkage with the terminal carboxylic acid group of PLGA [99,116]. The imaging modality can be also attached to the functional groups (e.g., amine group) of PLGA derivatives or appropriate linkers (e.g., bifunctional PEG linker) can be used to connect the imaging modality and PLGA [65]. In addition, the outer surface of PLGA NPs can be modified with imaging agents [115]. Exposed functional groups of PLGA NPs can participate in the reaction with imaging modalities [117,118]. Covalent bonding between PLGA (or PLGA NPs) and an imaging agent can reduce the loss of imaging agent prior to the localization of NPs to the tumor region following injection. To acquire a sufficient resolution for in vivo imaging, it is important to optimize the degree of substitution by the imaging agent. Imaging agents can be physically introduced to PLGA-based NPs [115]. After PLGA NPs are fabricated, the outer surface of NPs can be coated with the imaging agent by adsorption. However, this may risk an initial burst of imaging agent release following injection into the blood stream, and reduce the efficiency of visualizing target sites. Together with the solubilization of PLGA in the organic phase, several imaging agents can be added to the organic solvents (e.g., acetone, chloroform, dichloromethane, DMSO, and ethanol) during the fabrication of NPs $[33,119,120]$. To encapsulate an imaging modality in PLGA NPs, drug encapsulation efficiency and release rate also should be evaluated prior to application for in vivo imaging.

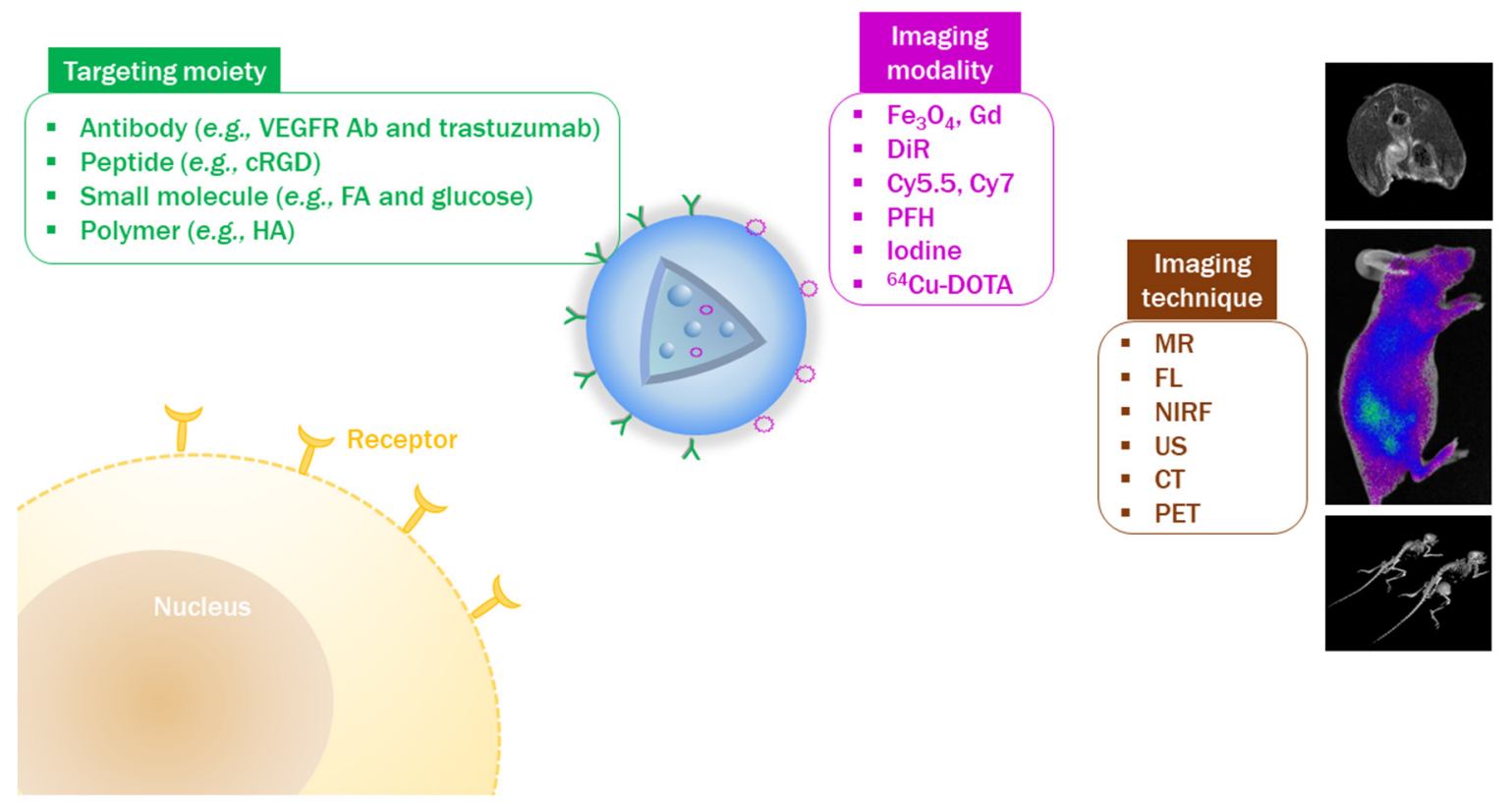

Figure 3. Evaluation of tumor-targeting efficiency by in vivo imaging techniques. Antibody (Ab); computed tomography (CT); cyclic Arg-Gly-Asp (cRGD); fluorescence (FL); folic acid (FA); gadolinium (Gd); hyaluronic acid (HA); magnetic resonance (MR); near-infrared fluorescence (NIRF); perfluorohexane (PFH); positron emission tomography (PET); 1,4,7,10-tetraazacyclododecane- $N, N^{\prime}, N^{\prime \prime}, N^{\prime \prime \prime}$-tetraacetic acid (DOTA); ultrasound (US); vascular endothelial growth factor receptor (VEGFR).

For magnetic resonance (MR) imaging, $T_{1}$-or $T_{2}$-weighed contrast agents can be introduced to PLGA NPs. In general, gadolinium (Gd) derivatives or iron oxide $\left(\mathrm{Fe}_{3} \mathrm{O}_{4}\right)$ NPs have been loaded to NPs to enhance the contrast in MR imaging [120-122]. 1,1'-Dioctadecyl-3,3,3',3'-tetramethylindotricarbocyanineiodide (DIR) has been widely used for in vivo fluorescence imaging $[123,124]$. Recently, many attempts have been made using near-infrared fluorescence (NIRF) imaging during the development of nanoformulations due to its deeper tissue penetration and lower tissue scattering property than fluorescence imaging [125]. In NIRF imaging, 
several kinds of fluorescence molecules (e.g., Cy5.5, Cy7, protoporphyrin IX [PpIX], and indocyanine green [ICG]) can be introduced to PLGA NPs $[33,126,127]$. Derivatives of NIRF dyes can be covalently conjugated to PLGA or encapsulated in PLGA NPs. For ultrasound (US) diagnosis, bubble-generating agents (e.g., perfluorohexane [PFH]) can be incorporated into the PLGA NPs [128,129]. In computed tomography (CT) imaging, several contrast agents (e.g., iodine derivatives and gold nanostructures) can be entrapped in PLGA NPs or coated on the outer surface of PLGA NPs $[115,130]$. Prior to application in in vivo imaging, the appropriate dose for visualizing the tumor tissue should be determined. Additionally, chemical modification and physical loading of imaging modalities should not affect the intrinsic biofunctions of PLGA NPs, including drug release, cellular binding, and in vitro/in vivo anticancer activities, in cancer theranostics.

Detection of signals from imaging modality-contained PLGA-based NPs in the body can indicate their biodistribution. Unfortunately, advantages and disadvantages for cancer diagnosis have been reported for each imaging modality [115]. For instance, MR imaging has high spatial resolution and relatively low sensitivity. In contrast, positron emission tomography (PET) imaging exhibits high sensitivity and low spatial resolution. Therefore, the combination of PET/MR imaging can provide a high sensitivity and high spatial resolution in the diagnosis of diseases. Therefore, in vivo imaging methods with dual or triple modalities have been combined to exploit the benefits of each imaging technique $[128,131]$. Multiple imaging modalities can enable more accurate tracing of NPs and the diagnostic ability of the disease state following systemic administration.

\subsection{Introduction of Tumor-Targeting Ligands to PLGA NPS}

To increase the tumor-targeting efficiency by active tumor-targeting strategies, diverse kinds of ligands can be introduced to PLGA-based NPs (Figure 3). Together with the "EPR effect" as a passive tumor targeting strategy, ligand-receptor interactions can improve tumor-targeting efficiency in cancer imaging and therapy $[25,27]$. Small molecules, polymers, proteins, peptides, and Abs can be linked to the PLGA backbone or the functional groups of PLGA derivatives [132]. Amine-, aldehyde-, carboxyl-, maleimide-, succinimidyl ester-, or sulfhydryl-functionalized PEG-linked PLGA can be coupled with various kinds of tumor-targeting ligands [132]. Amine-functionalized folate-polyethylene glycol (PEG) was conjugated to PLGA-PEG-COOH via a carbodiimide reaction to synthesize a folate-coupled PLGA-PEG derivative [133]. The amine group of an antibody (e.g., Herceptin ${ }^{\circledR}$ ) can be linked to the carboxylic acid groups on the outer surface of PLGA derivative-based NPs via $N$-(3-dimethylaminopropyl)- $N$-ethylcarbodiimide hydrochloride (EDC) and $N$-hydroxysuccinimide (NHS)-coupled reactions [129]. For peptide labeling, cyclic Arg-Gly-Asp (cRGD)-thiol (SH) was reacted with maleimide-functionalized PLGA-PEG NPs to prepare cRGD-linked PLGA-PEG NPs [128].

\subsection{Verification of Tumor Targetability by In Vivo Imaging}

Passive and active tumor-targeting approaches guiding drug delivery and cancer imaging can be assessed using several in vivo imaging techniques. In vivo and ex vivo imaging data can provide data on the pattern of biodistribution of fabricated NPs in the body. Interestingly, in vivo imaging can show the real-time distribution of fabricated NPs and the current status of cancer tissue without the need to sacrifice experimental animals. PLGA-based NPs guided by real-time imaging can increase the therapeutic efficacies of drug cargos. Recently, several studies have reported the in vivo tumor targeting capability of PLGA-based NPs by bioimaging techniques (Table 3). 
Table 3. Verification of tumor-targeting capability by in vivo imaging.

\begin{tabular}{|c|c|c|c|c|c|c|}
\hline Polymer & Drug & $\begin{array}{l}\text { Targeting } \\
\text { Material }\end{array}$ & $\begin{array}{l}\text { Target Receptor (Cell } \\
\text { Line) }\end{array}$ & $\begin{array}{l}\text { Imaging } \\
\text { Technique }\end{array}$ & $\begin{array}{l}\text { Imaging } \\
\text { Modality }\end{array}$ & Ref. \\
\hline PLGA-mPEG & $\begin{array}{l}\text { Platinum(II) } \\
\text { prodrug }\end{array}$ & cRGD & Integrin (SKOV-3 cells) & US and NIRF & PFH and Cy7 & [128] \\
\hline PLGA-PEG-COOH & PTX & Herceptin & $\begin{array}{l}\text { HER2 receptor (SKBR-3 } \\
\text { cells) }\end{array}$ & PA and US & PFH and SPIO & [129] \\
\hline PLGA-PEG-COOH & DOX & AS1411 aptamer & $\begin{array}{l}\text { Nucleolin receptor (C26 } \\
\text { cells) }\end{array}$ & MR & SPIO & [134] \\
\hline PLGA-PEG & DOX & Biotin & Biotin receptor (4T1 cells) & FL & DOX & [135] \\
\hline PLGA-PEG-COOH & DOX & FA & $\begin{array}{l}\text { Folate receptor (Bel-7402 } \\
\text { cells) }\end{array}$ & US and MR & $\mathrm{PFH}$ and $\mathrm{Fe}_{3} \mathrm{O}_{4}$ & [133] \\
\hline mPEG-PLGA-PLL & PTX & Anti-CA19-9 Ab & CA19-9 (capan-1 cells) & FL & $\operatorname{DiR}$ & [123] \\
\hline Maleimide-PEG-PLGA & Curcumin & $\mathrm{c}(\mathrm{RGDf}(\mathrm{N}-\mathrm{me}) \mathrm{V})$ & $\begin{array}{c}\alpha_{\mathrm{v}} \beta_{3}, \alpha_{\mathrm{v}} \beta_{5} \text {, and } \alpha_{5} \beta_{1} \\
\text { integrins (C6 cells) }\end{array}$ & FL & DiR & [124] \\
\hline PLGA & DTX & Angiopep-2 & LRP-1 (U87-MG cells) & $\begin{array}{l}\text { NIRF and } \\
\text { X-ray }\end{array}$ & $\begin{array}{l}\text { IR780 and gold } \\
\text { nanoshell }\end{array}$ & [130] \\
\hline PLGA-Glc & DTX & Glucose & $\begin{array}{l}\text { Glucose transporter } \\
\text { (Hep-2 cells) }\end{array}$ & NIRF & Cy5.5 & [70] \\
\hline PLGA & DTX & HA & $\begin{array}{c}\text { CD44 receptor } \\
\text { (MDA-MB-231 cells) }\end{array}$ & NIRF & Сy5.5 & [65] \\
\hline PLGA-PEG & $\begin{array}{l}\text { Curcumin } \\
\text { and PTX }\end{array}$ & $\begin{array}{l}\text { T7 (HAIYPRH) } \\
\text { peptide }\end{array}$ & Tf receptor (U87 cells) & $\begin{array}{l}\text { FL, X-ray, } \\
\text { and MR }\end{array}$ & DiR and MNP & [136] \\
\hline PLGA & $\mathrm{ZnPc}$ & $\begin{array}{c}\text { Anti-VEGFR-2 } \\
\mathrm{Ab}\end{array}$ & $\begin{array}{l}\text { VEGFR-2 (MDA-MB-231 } \\
\text { cells) }\end{array}$ & PA and US & $\mathrm{ZnPc}$ and $\mathrm{PFH}$ & [137] \\
\hline
\end{tabular}

Antibody (Ab); cyclic Arg-Gly-Asp (cRGD); 1,1'-dioctadecyl-3,3,3',3'-tetramethylindotricarbocyanineiodide (DIR); docetaxel (DTX); doxorubicin (DOX); fluorescence (FL); folic acid (FA); hyaluronic acid (HA); low-density lipoprotein receptor-related protein-1 (LRP-1); magnetic nanoparticle (MNP); magnetic resonance (MR); methoxypolyethylene glycol (mPEG); near-infrared fluorescence (NIRF); paclitaxel (PTX); perfluorohexane (PFH); photoacoustic (PA); phthalocyanine zinc $(\mathrm{ZnPc})$; poly $((\mathrm{D}, \mathrm{L})$ lactic-glycolic)acid-star glucose (PLGA-Glc); polyethylene glycol (PEG); poly-L-lysine (PLL); superparamagnetic iron oxide (SPIO); transferrin (Tf); ultrasound (US); vascular endothelial growth factor receptor (VEGFR)

Lipid-platinum prodrug (Pt(IV)) conjugate-loaded PLGA-PEG-cRGD NPs have been designed, and glutathione (GSH)-sensitive and US-triggered anticancer activities have been assessed [128]. cRGD-modified Pt(IV) NPs can target the tumor site via an EPR effect (passive tumor targeting) and cRGD-integrin receptor interactions (active tumor targeting). Under US exposure in the tumor region, the NP shell can be cracked, releasing the lipid-Pt(IV) prodrug. This can then adsorb onto the cellular membrane due to its amphiphilicity and move into the internal cellular space via passive diffusion. cRGD-modified Pt(IV) NPs were transported into the internal space of cancer cells via receptor-mediated endocytosis. Prodrug and NPs were released from the endosome in response to endogenous GSH. A combination of US and cRGD-modified Pt(IV) NPs enhanced the production of reactive oxygen species (ROS), resulting in mitochondrial-mediated apoptosis in cancer cells. The tumor-targeting efficiency of cRGD-modified Pt(IV) NPs was further verified with Cy7 incorporation by NIRF imaging in SKOV-3 tumor-bearing mouse models.

HER2-targeting PLGA NPs including PFH, paclitaxel (PTX), and superparamagnetic iron oxide (SPIO) were fabricated and their photothermal/chemo-therapeutic efficacies guided by photoacoustic (PA)/US imaging were evaluated [129]. Herceptin was conjugated to the outer surface of PLGA-based NPs to target the HER2 receptor. SPIO and PFH were included in the NPs for PA and US imaging, respectively. SPIO can convert external near-infrared (NIR) light to thermal energy and can thus be used for the photothermal ablation of tumors. It can then be combined with the chemotherapeutic effects of PTX for the treatment of breast cancers. Photothermal heating of SPIO can be transferred to PLGA polymer, which can make the structure of the polymer rubbery. Then, a drug with poor aqueous solubility (PTX) can be diffused from the NPs. The tumor-targeting efficiency of Herceptin-modified NPs was assessed by photoacoustic (PA)/US bimodal imaging in the SKBR-3 
tumor-xenograft mouse model [129]. Under NIR laser irradiation, Herceptin-modified NPs containing PHF, PTX, and SPIO exerted superior tumor growth inhibition based on the synergism of photothermaland chemo-therapeutic efficacy.

Angiopep-2-linked PLGA@Au NPs including docetaxel (DTX) were prepared and then NIR laser-triggered drug release and chemo-photothermal therapeutic efficacies were evaluated [130]. Organic-inorganic hybrid NPs based on a core-shell structure were designed with an outer Au shell that can be used for photothermal therapy (PTT) by converting the NIR laser to heat energy and as an X-ray imaging agent. Angiopep-2 carried by NPs can be efficiently internalized in U87MG cells via receptor-mediated endocytosis and have presented improved anticancer activity. X-ray and NIR thermal imaging analyses were performed to demonstrate the tumor-targeting efficiency and therapeutic potentials. Angiopep-2-conjugated Au nanoshell/PLGA/DTX NPs exhibited the anti-glioma activity in U87MG tumor-bearing mouse models [130].

PLGA NPs coated with amphiphilic HA derivative (HA-ceramide [HACE]) were developed to target the CD44 receptor for drug delivery [65]. HACE was composed of a hydrophilic backbone (HA) and a hydrophobic segment (CE); thus, PLGA NPs can be entrapped in the internal hydrophobic cavity of self-assembled HACE nanostructures. DTX was encapsulated in PLGA-based NPs as a poorly water-soluble chemotherapeutic agent. Higher levels of HACE-coated PLGA NPs were internalized by cancer cells expressing the CD44 receptor- (MDA-MB-231 cells) compared with cancer cells negative for the CD44 receptor (NIH3T3 cells). In mice bearing MDA-MB-231 tumors, HACE-PLGA NPs accumulated at higher levels in tumor tissue compared with PLGA NPs.

\section{In Vivo Anticancer Activities of PLGA-based NPs}

\subsection{Parameters for Assessing In Vivo Antitumor Activity}

Various PLGA NPs developed as anticancer therapies have been applied to animals to demonstrate superiority versus conventional interventions. Currently, standard techniques used to assess in vivo antitumor activity include tumor size measurement and survival analysis. Specifically, cancer cell-lines are xenografted in animals, who are often immunocompromised, and the tumor volume or survival rate is monitored over time in response to treatment. Tumor volume is determined using the modified ellipsoid formula: (tumor length $\times$ tumor width $\left.{ }^{2}\right) / 2[138,139]$. However, in some models where direct tumor measurements are not available (e.g., tumor inside the skull, lung, or liver), the tumor in the scanned image or the weight of the dissected tumor can be used to substitute for volume data [140,141]. The survival rate is defined as the percentage of survivors in a group over a specific period after diagnosis. From the survival rate versus time function (i.e., Kaplan-Meier curve), the median survival value can be estimated and used to assess the effectiveness of the treatments [142,143].

\subsection{Key Factors for Improved Antitumor Efficacy}

Most PLGA NPs developed for anticancer therapy share therapeutic advantages, such as passive targeting via the EPR effect and controlled drug release (Figure 4). Moreover, further chemical or physical modifications with other compounds provide specific functions not provided by the unmodified NPs. These properties have been translated into significant improvements in antitumor activity, as shown in Table 4. 


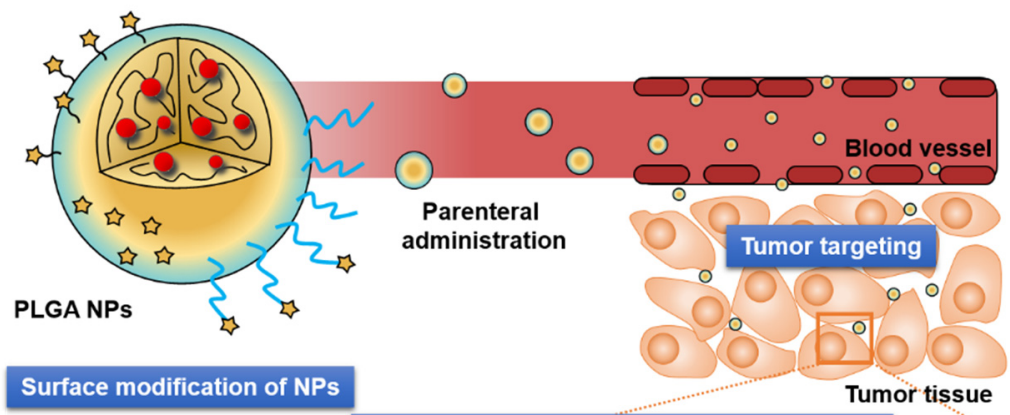

Surface modification of NPs Combination with
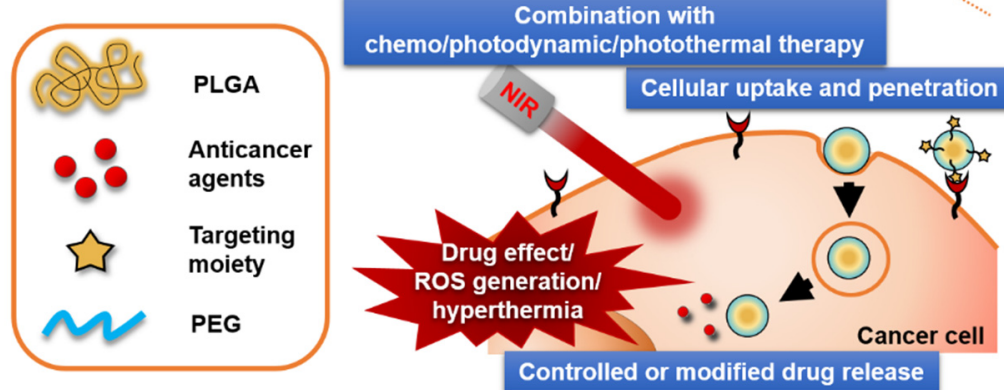

Figure 4. Crucial factors that affect the antitumor activities of PLGA NPs. Polyethylene glycol (PEG); reactive oxygen species (ROS).

\subsubsection{Controlled Release and EPR Effect}

The clinical value of anticancer agents is often highly compromised due to the dose-limiting severe side effects (e.g., renal and gastrointestinal toxicities). Many approaches using PLGA NPs have been developed to avoid the accumulation of drug in normal tissues (Table 4). Moreno et al. reported that cisplatin (CP)-loaded PLGA NPs exhibited comparable antitumor efficacy to free CP [144]. However, the PLGA NPs presented reduced systemic toxicity in terms of body weight and blood urea nitrogen (BUN). The authors suggested that the results were due to the controlled release of $\mathrm{CP}$ and the passive targeting of PLGA NPs, as well as the induction of apoptosis.

PEGylation is one of the most extensively studied strategies to enhance the antitumor efficacy of PLGA NPs, and increases the circulation time of NPs in the bloodstream. This pharmacokinetic advantage increases the chance of tumors being targeted by NPs. Interestingly, CP-loaded NPs prepared with the mPEG-PLGA copolymer resulted in an enhanced survival rate compared with free $\mathrm{CP}$, which was not observed when using the unmodified PLGA NPs [144,145]. Similarly, mPEG-PLGA NPs co-loaded with gemcitabine (GEM) and betulinic acid (BA) resulted in a significant reduction in tumor volume compared with GEM + BA solution in mice with Ehrlich ascites carcinoma xenografts [146].

\subsubsection{Targeted Delivery}

The surface modification of PLGA NPs with tumor-targeting moieties (i.e., active-targeting strategy) can also enhance anticancer activity [147]. Typical examples can be found in studies using PTX-loaded PLGA NPs, in which the targeting moieties were tethered with the aid of PEG linkers. Liang et al. reported that the addition of FA, a small molecule ligand of folate receptor, to the surface of PTX-loaded PLGA NPs resulted in increased reduction in tumor volume compared with unmodified NPs in HEC-1A tumor-xenografted mice [148]. A comparable improvement was observed in studies exploiting peptides (iNGR; CRNGRGPDC) as a tumor-targeting moiety. The median survival of mice bearing intracranial U87-MG glioblastoma was 1.6-fold longer following treatment with PTX-loaded iNGR-PEG-PLGA NPs compared with unmodified NPs [149]. Aptamer (AS1411) conjugation also augmented the tumor inhibitory activity of PLGA NPs. The average tumor volume in C6 tumor-xenografted mice following treatment with PTX-loaded AS1411-PEG-PLGA NPs was reduced by $33 \%$ compared with those treated with the non-targeted NPs [140]. 
The targeting moieties can be attached indirectly. The most straightforward approach was based on the charge-charge interaction between the targeting moiety and the NP surface. This was demonstrated by $\mathrm{Wu}$ et al., who coated the surface of PLGA NPs modified with a positively charged surfactant, vitamin E-oligo(methyl diglycol L-glutamate) with the anionic polymer, HA [143]. In that study, the HA-coated PLGA (HPLGA) NPs loaded with DTX prolonged median survival 1.4-fold compared with free DTX in orthotopic A549-Luc lung xenograft model. Another approach has exploited the strong binding affinity between avidin and biotin. Biotin-conjugated RVG29 (fragment of the rabies virus coat protein) was successfully attached to avidin-palmitate anchored on the surface of camptothecin (CPT)-loaded PLGA NPs; however, no significant difference was found in median survival compared with the biotin-attached CPT-loaded PLGA NPs (control) in mice bearing intracranial glioblastoma [142]. However, doxorubicin (DOX)-loaded lecithin hybridized PLGA NPs resulted in a reduced mean tumor area $\left(9.6 \pm 10.7 \mathrm{~mm}^{2}\right)$ compared with free DOX $\left(21.7 \pm 13.4 \mathrm{~mm}^{2}\right)$ in orthotopic glioblastoma rat models [141]. This was attributed to the adsorption of apolipoprotein A-1, an endogenous targeting moiety in the bloodstream, to the lecithin-rich surface of NP after systemic administration.

\subsubsection{Cellular Uptake and Penetration}

Factors regarding cellular uptake and penetration are also closely related to the antitumor activity of PLGA NPs. One interesting approach was reported by Zhang et al. [150], who co-loaded methenamine mandelate (MM), a urinary antibacterial agent, with $\mathrm{NaHCO}_{3}$ in PLGA NPs. Following the entry of NPs cancer cells via the endo-lysosomal pathway, $\mathrm{NaHCO}_{3}$ generates $\mathrm{CO}_{2}$ bubbles due to the acidic nature of endo-lysosomes. The bubbles broke down the structural integrity of the NPs and the subsequent release of MM resulted in formaldehyde production in the cancer cells. This $\mathrm{pH}$-responsive drug release resulted in greater inhibition of tumor growth in MCF-7 tumor xenografted mice compared with NPs without $\mathrm{NaHCO}_{3}$. Another approach reported by Wang et al. utilized CPP to decorate the surface of PLGA NPs [90]. In that study, tumor penetration and intranuclear delivery of DOX were achieved by the alkyl-chained LMWP anchored in PLGA NPs, resulting in near complete arrest of tumor growth in MCF-7/ADR tumor-xenografted mice.

\subsubsection{Combination with Photodynamic Therapy (PDT) and/or PTT}

PDT and PTT have gained much attention based on their effectiveness in cancer treatment [7, 43,151,152]. Combination treatment with chemotherapy, PDT, and PTT using multifunctional PLGA NPs has been investigated. A photosensitizer (e.g., 5-aminolevulinic acid, hypocrellin A, meso-tetra hydroxyphenylchlorine [mTHPC], pheophorbide a [Pba], and PpIX) and/or photothermal agents (e.g., ICG) can be introduced into PLGA NPs by encapsulation or adsorption [153-158]. FA-modified PLGA NPs including Pba have been fabricated, and enhanced anticancer activities based on PDT against gastric cancer (MKN28 tumor) after intravenous injection have been demonstrated [155]. Peng et al. reported the use of polydopamine (PDA) and D- $\alpha$-tocopheryl polyethylene glycol 1000 succinate (TPGS)-coated DTX-loaded PLGA NPs [159]. When co-treated with NIR laser irradiation, this nanoplatform resulted in an approximately 10 -fold reduction in tumor size and weight compared with Taxotere ${ }^{\circledR}$, a commercial formulation of DTX, in MCF-7/ADR tumor-xenografted mice. This result was explained by the augmented photothermal conservation property by PDA and the reduced multi-drug resistance by TPGS. Similarly, gold- or polyaniline-modified PLGA NPs also resulted in effective tumor suppression in the presence of NIR irradiation $[130,160]$. These therapeutic advancements were ascribed to the synergistic effects of chemo/photodynamic/photothermal therapy. 
Table 4. Summary of successful in vivo cancer therapy using various types of PLGA NPs.

\begin{tabular}{|c|c|c|c|c|}
\hline Drug@Formulation & Target (Cell Line) & Functions & Therapeutic Benefits & Ref. \\
\hline $\begin{array}{c}\mathrm{As}_{2} \mathrm{O}_{3} @ \text { PLGA-PEG/LA } \\
\text { NPs }\end{array}$ & $\begin{array}{l}\text { Liver cancer } \\
\text { (HepG2 cells) }\end{array}$ & $\begin{array}{l}\text { EPR effect; controlled release of } \\
\qquad \mathrm{As}_{2} \mathrm{O}_{3}\end{array}$ & $\begin{array}{c}\text { 1.49- and } 1.09 \text {-fold reduction in tumor } \\
\text { volume compared with saline and free } \\
\mathrm{As}_{2} \mathrm{O}_{3} \text {, respectively, in HepG2 } \\
\text { tumor-bearing mice }\end{array}$ & [147] \\
\hline $\begin{array}{c}\text { CBP/ICG@FA-PEG-PLGA } \\
\text { NPs }\end{array}$ & $\begin{array}{l}\text { Breast cancer } \\
\text { (MCF-7 cells) }\end{array}$ & $\begin{array}{l}\text { EPR effect; targeted delivery via } \\
\text { the folate receptor; combination of } \\
\text { chemo, photodynamic, and } \\
\text { photothermal therapy }\end{array}$ & $\begin{array}{l}\text { The strongest tumor growth } \\
\text { suppression potentials in NPs with NIR } \\
\text { laser irradiation group rather than the } \\
\text { other group }\end{array}$ & [157] \\
\hline CPT@RVG-PLGA NPs & $\begin{array}{c}\text { Glioblastoma } \\
\text { (GL261-Luc2 cells) }\end{array}$ & Brain-specific delivery of CPT & $\begin{array}{l}\text { Prolonged tumor doubling time and } \\
\text { increased median survival }(3.15 / 23 \\
\text { days) compared with either saline } \\
\text { (2.46/16.5 days) or blank RVG-PLGA } \\
\text { (2.50/19 days) in mice bearing } \\
\text { intracranial GL261-Luc2 gliomas }\end{array}$ & [142] \\
\hline CP@mPEG-PLGA NPs & $\begin{array}{l}\text { Colorectal cancer } \\
\text { (HT } 29 \text { cells) }\end{array}$ & $\begin{array}{l}\text { EPR effect; prolonged CP } \\
\text { residence in the systemic } \\
\text { circulation }\end{array}$ & $\begin{array}{c}\text { Increased survival rate of HT } 29 \\
\text { tumor-bearing mice compared with } \\
\text { saline, free CP, or blank NPs }\end{array}$ & [145] \\
\hline $\begin{array}{l}\text { DOX@lecithin-PLGA } \\
\text { NPs }\end{array}$ & $\begin{array}{l}\text { Glioblastoma (GB } \\
\text { 101/8 cells) }\end{array}$ & $\begin{array}{c}\text { Adsorption of apolipoprotein A-1 } \\
\text { on the surface of the NPs and } \\
\text { subsequent improvement of } \\
\text { endocytosis into vascular } \\
\text { endothelial cells via lipoprotein } \\
\text { receptors }\end{array}$ & $\begin{array}{l}\text { Reduced mean tumor area }(9.6 \pm 10.7 \\
\left.\mathrm{mm}^{2}\right) \text { compared with vehicle }(32.1 \pm 3.8 \\
\left.\mathrm{mm}^{2}\right) \text { and free DOX }\left(21.7 \pm 13.4 \mathrm{~mm}^{2}\right) \\
\text { in rats with orthotopic glioblastoma }\end{array}$ & [141] \\
\hline $\begin{array}{l}\text { DOX@LMWP/PLGA } \\
\text { NPs }\end{array}$ & $\begin{array}{c}\text { Breast cancer } \\
\text { (MCF-7/ADR cells) }\end{array}$ & $\begin{array}{c}\text { Targeted nuclear delivery of DOX; } \\
\text { tumor penetration by breaking } \\
\text { down the diffusion barriers } \\
\text { caused by interstitial fluid } \\
\text { pressure }\end{array}$ & $\begin{array}{l}\text { Near-complete tumor growth arrest in } \\
\text { MCF-7/ADR tumor-bearing mice } \\
\text { compared with vehicle, free DOX, or } \\
\text { DOX-loaded PLGA NPs }\end{array}$ & [90] \\
\hline $\begin{array}{c}\text { DTX@PLGA-PDA-TPGS } \\
\text { NPs + NIR }\end{array}$ & $\begin{array}{c}\text { Drug-resistant } \\
\text { breast cancer } \\
\text { (MCF-7/ADR cells) }\end{array}$ & $\begin{array}{l}\text { Improved photothermal } \\
\text { conservation by PDA; inhibition } \\
\text { of P-glycoprotein by TPGS }\end{array}$ & $\begin{array}{c}\text { Approximate } 10 \text {-fold reduction in } \\
\text { tumor size and weight compared with } \\
\text { Taxotere }^{\circledR}\end{array}$ & [159] \\
\hline $\begin{array}{c}\text { DTX@ANG/GS/PLGA } \\
\text { NPs + NIR }\end{array}$ & $\begin{array}{l}\text { Glioblastoma } \\
\text { (U87-MG cells) }\end{array}$ & $\begin{array}{l}\text { DTX accumulation in the tumor; } \\
\text { heat-induced tumor cell damage }\end{array}$ & $\begin{array}{l}\text { The greatest tumor inhibition rate } \\
\text { among all groups comprising saline, } \\
808 \mathrm{~nm} \text { irradiation, free DTX, } \\
\text { GS/PLGA/DTX NPs, and } \\
\text { ANG/GS/PLGA/DTX NPs. }\end{array}$ & [130] \\
\hline $\begin{array}{c}\text { GEM/BA@mPEG-PLGA } \\
\text { NPs }\end{array}$ & $\begin{array}{l}\text { Ehrlich ascites } \\
\text { carcinoma (EAC } \\
\text { cells) }\end{array}$ & $\begin{array}{l}\text { Combination drug delivery; } \\
\text { improved pharmacokinetic } \\
\text { properties }\end{array}$ & $\begin{array}{l}\text { Reduced mean tumor volume }(195.5 \\
\left.\mathrm{mm}^{3}\right) \text { compared with saline }(1236.5 \\
\left.\mathrm{mm}^{3}\right) \text {, GEM solution }\left(553.1 \mathrm{~mm}^{3}\right), \mathrm{GEM} \\
\mathrm{NPs}\left(367.8 \mathrm{~mm}^{3}\right) \text {, or GEM + BA } \\
\text { solution }\left(213.5 \mathrm{~mm}^{3}\right) \text { in mice bearing } \\
\text { Ehrlich tumors }\end{array}$ & [146] \\
\hline $\begin{array}{c}\mathrm{MM} @ \mathrm{NaHCO}_{3} / \mathrm{PLGA} \\
\mathrm{NPs}\end{array}$ & $\begin{array}{l}\text { Breast cancer } \\
\text { (MCF-7 cells) }\end{array}$ & $\begin{array}{c}\text { EPR effect; } \mathrm{pH} \text {-responsive } \\
\text { degradation of NPs due to } \mathrm{CO}_{2} \\
\text { bubbles generated from } \mathrm{NaHCO}_{3} \\
\text { and subsequent rapid release of } \\
\text { MM in lysosomes }\end{array}$ & $\begin{array}{l}\text { Highest tumor growth inhibition } \\
\text { compared with vehicle, blank NPs, or } \\
\text { MM-loaded NPs in MCF-7 } \\
\text { tumor-xenografted mice }\end{array}$ & [150] \\
\hline $\begin{array}{l}\text { MTX@PANI-LT-PLGA } \\
\text { NPs + NIR }\end{array}$ & $\begin{array}{l}\text { Breast cancer } \\
\text { (MDA-MB-231 } \\
\text { cells) }\end{array}$ & $\begin{array}{c}\text { Targeting somatostatin receptors } \\
\text { by LT modification; hyperthermia } \\
\text { effect }\end{array}$ & $\begin{array}{c}\text { Higher tumor suppression compared } \\
\text { with saline, free MTX, PANI PLGA NPs, } \\
\text { MTX/PANI PLGA NPs, or MTX/PANI } \\
\text { LT-PLGA NPs in mice }\end{array}$ & [160] \\
\hline
\end{tabular}


Table 4. Cont.

\begin{tabular}{cccc}
\hline Drug@Formulation & Target (Cell Line) & Functions & Therapeutic Benefits \\
\hline $\begin{array}{c}\text { PTX@AS1411-PEG-PLGA } \\
\text { NPs }\end{array}$ & Glioma (C6 cells) & $\begin{array}{c}\text { Targeted delivery to the tumor } \\
\text { and angiogenic blood vessels by } \\
\text { AS1411 aptamer }\end{array}$ & $\begin{array}{c}\text { The highest average tumor inhibition } \\
\text { based on tumor volume and weight } \\
(81.68 \text { and } 79.93 \%), \text { compared with } \\
\text { non-targeted NPs }(66.95 \text { and } 68.69 \%) \\
\text { and Taxol }{ }^{\circledR}(68.69 \text { and } 46.75 \%)\end{array}$ \\
\hline [140]
\end{tabular}

Adriamycin (ADR); angiopep-2 (ANG); betulinic acid (BA); camptothecin (CPT); carboplatin (CBP); cisplatin (CP); CNGRC peptide (cNGR); CRNGRGPDC peptide (iNGR); D- $\alpha$-tocopheryl polyethylene glycol 1000 succinate (TPGS); docetaxel (DTX); doxorubicin (DOX); enhanced permeability and retention (EPR); folic acid (FA); fragment of rabies virus coat protein (RVG); gemcitabine (GEM); gold nanoshell (GS); hyaluronic acid-coated PLGA (HPLGA); indocyanine green (ICG); lactose acid (LA); lanreotide (LT); low molecular weight protamine (LMWP); luciferase (Luc); methenamine mandelate (MM); methotrexate (MTX); methoxypolyethylene glycol (mPEG); near-infrared (NIR); paclitaxel (PTX); polyaniline (PANI); polydopamine (PDA); polyethylene glycol (PEG).

\section{In Vivo Pharmacokinetics of PLGA-Based NPs}

The pharmacokinetics of DTX-loaded PEGylated PLGA NPs (DTX-PEG-PLGA NPs) was assessed in Balb/C mice bearing C26 tumors [161]. The PEGylated NPs exhibited a markedly delayed plasma clearance (CL) as shown in Table 5. Following the administration of DTX-PEG-PLGA NPs, the plasma DTX levels remained much higher after $24 \mathrm{~h}$ compared with those of free DTX solution and DTX-loaded PLGA NPs. In contrast, the DTX solution and DTX-loaded PLGA NPs were quickly eliminated from the systemic circulation and their plasma concentrations $2 \mathrm{~h}$ after dosing were low. These data suggest that the NPs with a steric PEG barrier would prevent their rapid uptake by a mononuclear phagocyte system and improve their circulatory half-life. Shah et al. reported the pharmacokinetics of PTX-loaded PLGA NPs surface-modified with Tf and Pluronic ${ }^{\circledR}$ P85 in male Sprague-Dawley (SD) rats bearing C6 glioma [89]. PTX in solution administered intravenously was rapidly cleared from blood whereas PTX loaded in different NP formulations was retained in blood for longer, indicating the long circulation properties of drug-loaded NPs (Table 5). This increase in residence time may be attributed to decreased opsonization from blood due to the smaller size (less than $200 \mathrm{~nm}$ ) and hydrophilicity (imparting stealthiness) of the NPs [162].

Milane et al. reported the biodistribution and pharmacokinetics of polymer-blend (PLGA-PEG-EGFR-targeting peptide) NPs loaded with lonidamine in an orthotopic animal model of multidrug-resistant breast cancer [163]. As shown in Table 5, the NPs containing EGFR-targeting peptide (targeted NPs) increase the plasma AUC, MRT, and $t_{1 / 2}$ of lonidamine relative to lonidamine administered as a solution. Furthermore, the targeted NPs decrease the tumor $\lambda_{z}$, increase the tumor MRT, and increase the AUC relative to drug solution. Collectively, although exact mechanisms remain unclear, the NP formulations improve the tumor pharmacokinetics relative to drug solution, with the targeted NPs providing a slight advantage in terms of the pharmacokinetic parameters of lonidamine relative to the non-targeted NPs.

The comparative pharmacokinetics of platinum (Pt)-loaded PLGA-PEG NPs and Pt prodrug was evaluated in male SD rats following intravenous administration of the maximal tolerated doses of the compounds (40 and $20 \mathrm{mg} / \mathrm{kg}$, respectively) [164]. Pt remaining in the systemic circulation $1 \mathrm{~h}$ after administration was 77\% following administration of Pt-PLGA-b-PEG-NPs and $15.6 \%$ following administrated of the Pt prodrug, whereas this value for $\mathrm{CP}$ has been reported as $1.5 \%$ in the literature [165]. The mean AUC for total Pt in the blood was about $26 \%$ of that observed in plasma (Table 5), suggesting that Pt is not extensively distributed in red blood cells. After a single intravenous dose of the Pt-loaded NPs, both the liver and spleen showed the highest Pt concentration at $24 \mathrm{~h}$. In the kidney, which is the primary target organ of cisplatin toxicity, the Pt-loaded NPs 
resulted in lower Pt levels than the Pt prodrug. The lower Pt level in the kidney indicated that the NP system would exhibit reduced nephrotoxicity compared with that of CP. Notably, the 24-h cumulative Pt excretion after Pt-loaded PLGA-PEG NPs was about 17 times less than after cisplatin treatment. This difference is probably due to the characteristics of Pt compounds, which can bind to protein or other tissue compositions firmly through covalent bonds.

Table 5. Summary of in vivo pharmacokinetic parameters altered by PLGA-based NPs.

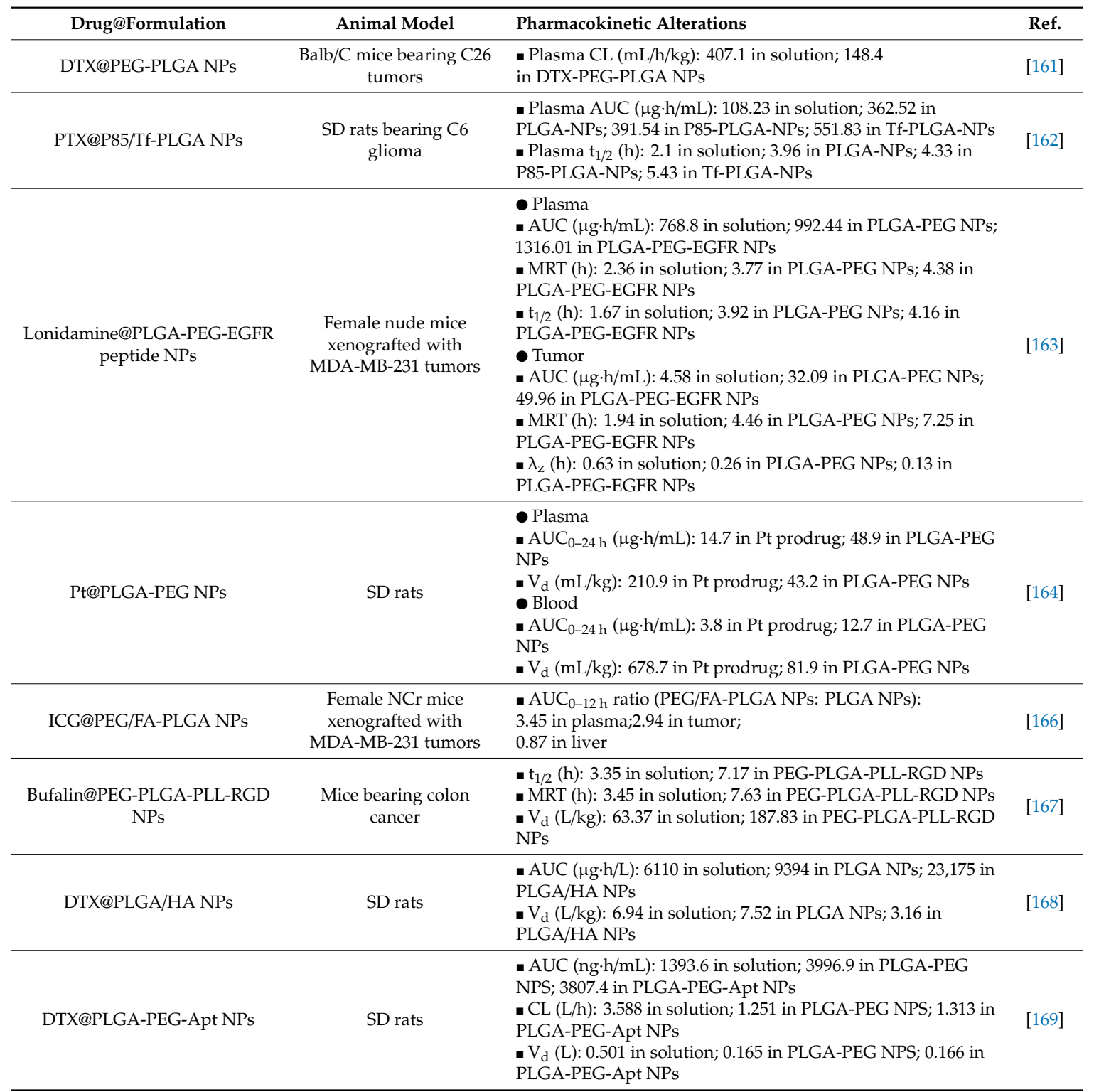

Aptamer (Apt); Arg-Gly-Asp (RGD); docetaxel (DTX); epidermal growth factor receptor (EGFR); folic acid (FA); hyaluronic acid (HA); indocyanine green (ICG); platinum (Pt); Pluronic ${ }^{\circledR}$ P85 (P85); polyethylene glycol (PEG); poly-L-lysine (PLL); Sprague-Dawley (SD); transferrin (Tf).

Ma et al. reported the tissue distribution of ICG-loaded PLGA NPs modified with PEG and FA in mice xenografted with MDA-MB-231 tumors, which present high expression of folate receptor [166]. As shown in Table 5, the plasma $\mathrm{AUC}_{0-12 \mathrm{~h}}$ in the dual-modified PLGA NPs was higher than the corresponding $\mathrm{AUC}_{0-12 \mathrm{~h}}$ in the non-modified PLGA NPs, except for the $\mathrm{AUC}_{0-12 \mathrm{~h}}$ in liver, which was lower. Such an increase and decrease confirmed the function of PEG, which enabled the NPs to circulate longer in blood and partially escape elimination by the liver. The tumor $\mathrm{AUC}_{0-12 \mathrm{~h}}$ of the dual-modified PLGA NPs was three-fold higher than that of the non-modified PLGA NPs, strongly 
demonstrating the tumor-targeting ability of the dual-modified PLGA NPs. Since both PEG and FA were present on the dual-modified NPs, it is difficult for this study to reveal which factor contributed more for tumor targeting. However, it is speculated that longer systemic circulation is a prerequisite for tumor targeting via an EPR effect, and simultaneously FA enhances the affinity of the NPs with folate receptor-expressing tumor cells, resulting in the accumulation and intracellular uptake.

A pharmacokinetic study investigating bufalin-loaded NPs comprised of mPEG, PLGA, PLL, and cRGD was performed in mice with SW620 colon cancer [167]. In plasma, bufalin was detectable even $24 \mathrm{~h}$ after injection in mice treated with bufalin-loaded mPEG-PLGA-PLL-cRGD NPs (BNPs), while bufalin was not detected in the plasma of mice treated with free bufalin. The MRT and elimination half-life of BNPs were significantly greater than those of free bufalin (Table 5). Huang et al. reported the pharmacokinetics of biodegradable DTX-loaded self-assembled NPs made of PLGA/HA block copolymers (PLGA/HA NPs) in SD rats [168]; both DTX-loaded PLGA and the PLGA/HA NPs resulted in some increase in the plasma levels of DTX compared with free DTX. The $V_{d}$ for the PLGA/HA NPs was only half of that reported for PLGA NPs or free DTX, indicating greater retention of active DTX in plasma circulation when loaded into PLGA/HA NPs. As shown in Table 5, the AUC for the PLGA/HA NPs was 2.5- and 3.8-fold higher than that of the PLGA NPs and free DTX, probably due to HA shell. Collectively, the PLGA/HA NPs could prolong the circulation of DTX in the plasma.

Chen et al. reported the pharmacokinetics of DTX-loaded PLGA-PEG NPs modified with anti-prostate-specific membrane antigen (PSMA) aptamer in LNCaP tumor-xenografted BALB/c mice for targeted delivery of DTX to prostate tumors [169]. The CL and $V_{d}$ of DTX decreased when DTX was applied in encapsulated formulations, suggesting favorable conditions for enhanced systemic exposure, which is reflected by the increases in AUC (Table 5). The DTX solution presented higher distribution to the heart and lower distribution to other organs, including the liver, spleen, lung, and kidney, compared with PLGA-PEG-apt NPs. Generally, NPs administered intravenously are readily entrapped in the RES, a unique microstructure abundant in the spleen, liver, and lung [170].

In a previous study [171], curcumin, a clinically promising anticancer phytochemical, exhibited a very short half-life of $\sim 8 \mathrm{~min}$ following intravenous dosing as a free form in female BALB/c nude mice. However, PLGA-PEG NPs conjugated with EGFR-targeting GE11 peptide for breast cancer therapy prolonged the half-life to $\sim 6 \mathrm{~h}$. This provided further evidence that the sustained release of curcumin from the NP formulation and/or protection from elimination in the systemic circulation could prolong the period of tumor exposure to curcumin. Recently, it was reported that anti-EGFR protein-anchored PLGA-PEG NPs (immunonanoparticle, INP) for breast cancer therapy significantly enhanced tumor PTX concentrations by approximately 93-fold, compared to PLGA-PEG NPs and free PTX in athymic mice [94]. Paolini et al. developed galactosamine-modified PLGA NPs with a hydrodynamic diameter of $63 \mathrm{~nm}$ for the liver-specific delivery of bergamottin, a natural CYP3A4-inhibiting compound [172]. The bergamottin-loaded PLGA-galactosamine NPs efficiently inhibited CYP3A4 in vitro, and the highest accumulation was observed in hepatocytes. Compared with DTX treatment alone in nude mice bearing MDA-MB-231 tumors, co-treatment with NPs significantly improved the delay in tumor growth and demonstrated a major improvement in overall survival (survival rate of $67 \%$ versus $0 \%$ at day 55). Ahmad et al. assessed in situ intestinal transport and in vivo pharmacokinetics of DTX-loaded CS-coated PLGA NPs (DTX-CS-PLGA NPs), which were developed for target therapy of intestinal cancer [173]. DTX-CS-PLGA and DTX-PLGA NPs, along with GF120918, presented a 5and 2.2-fold enhancement, respectively, in apparent intestinal permeability in a rat ileum permeation study. Similarly, significantly higher $C_{\max }, T_{\max }$, and AUC were observed following administration of DTX-CS-PLGA and DTX-PLGA NPs compared with free DTX suspension in rats. The higher $T_{\max }$ is consistent with the sustained in vitro release profile, whereas the higher $C_{\max }$ and AUC for the nanoformulations may be attributed to the enhanced intestinal absorption of DTX. The possible mechanisms of the enhanced DTX absorption include encapsulation of DTX, protecting it from GI shielding, avoiding CYP and P-glycoprotein recognition, and endocytosis into enterocytes (direct uptake of NPs) [173]. 


\section{Current Status and Challenges of PLGA-Based Formulations for Clinical Applications}

There have been many developments in PLGA-based formulations for the diagnosis and therapy of diseases in research status [59-62]. Several pharmaceutical products based on PLGA have been prescribed as follows: Arestin ${ }^{\circledR}$ (minocycline $\mathrm{HCl}$, microsphere, periodontal; OraPharma), Bydureon ${ }^{\circledR}$ (exenatide, microsphere, subcutaneous; AstraZeneca PLC), Eligard ${ }^{\circledR}$ (leuprolide acetate, in situ forming gel, subcutaneous; Tolmar Pharmaceuticals, Inc.), Lupron $\operatorname{depot}^{\circledR}$ (leuprolide acetate, microsphere, intramuscular; AbbVie Inc.), Ozurdex ${ }^{\circledR}$ (dexamethasone, implant, intravitreal; Allergan), Signifor LAR $^{\circledR}$ (pasireotide pamoate, microsphere, intramuscular; Norvatis Pharmaceuticals Corp.), Vivitrol ${ }^{\circledR}$ (Naltrexone, microsphere, intramuscular; Alkermes, Inc.), and Zoladex ${ }^{\circledR}$ (goserelin acetate, implant, subcutaneous; AstraZeneca PLC). Micellar structure based on mPEG-poly(D,L-lactide) including PTX has been also developed and used in clinics as Genexol ${ }^{\circledR}$ PM (Samyang Biopharm). Unfortunately, there was little progress in the commercialization of PLGA-based NPs for cancer imaging and therapy. For the clinical translation of developed PLGA NPs, following drawbacks should be overcome; poor drug loading capacity (in spite of high drug encapsulation efficiency), high initial burst release rate of drug, generation of acidic products after its biodegradation, difficulty in scale-up process, and nanotoxicology [174]. In view of the toxicological issue, the influences of degraded products (LA and GA) of PLGA to the major organs and tissues were investigated [175]. In that literature [175], the oral administration of PLGA NPs in rats exhibited minimal toxicities on liver and intestine and no toxicity in brain, kidney, and lung. Recent endeavors in the areas of regulation and mass production may accelerate the launch of PLGA-based nanoformulations for cancer therapy in the market.

\section{Conclusions}

A variety of nanosystems based on PLGA or PLGA derivatives have been developed for cancer imaging and treatment. Because of the biocompatibility and biodegradability of PLGA, its potential for clinical application may be high compared with that of other materials. As naive PLGA-based NPs can only target tumors passively through the EPR effect, several functional groups (i.e., targeting ligands) have been introduced as active tumor-targeting strategies. Chemical or physical modulation of PLGA NPs can control drug cargo release, endocytosis in cancer cells, in vivo tumor targeting efficiency, in vivo anticancer activities, and in vivo pharmacokinetics following their intravenous administration. However, for clinical application, mass production process of those PLGA-based NPs should be established and the safety of surface-engineered PLGA NPs has to be thoroughly identified. The introduction of biosafe or commercially available functional materials into PLGA-based NPs may augment their anticancer efficacy and attenuate unwanted adverse effects.

Author Contributions: Conceptualization, I.-S.Y., H.-J.C.; investigation, K.-T.K., J.-Y.L., I.-S.Y., H.-J.C.; writing-original draft preparation, K.-T.K., J.-Y.L., I.-S.Y., H.-J.C.; writing-review and editing, I.-S.Y., D.-D.K., H.-J.C.; visualization, K.-T.K., J.-Y.L., I.-S.Y., H.-J.C.; funding acquisition, H.-J.C.

Funding: This research was funded by the Basic Science Research Program through the National Research Foundation of Korea (NRF) funded by the Ministry of Science, ICT and Future Planning and the Ministry of Education (No. NRF-2017R1E1A1A01074584 and NRF-2018R1A6A1A03025582).

Conflicts of Interest: The authors declare no conflict of interest.

\section{References}

1. Choi, Y.H.; Han, H.K. Nanomedicines: Current status and future perspectives in aspect of drug delivery and pharmacokinetics. J. Pharm. Investig. 2018, 48, 43-60. [CrossRef] [PubMed]

2. Elzoghby, A.O.; Hemasa, A.L.; Freag, M.S. Hybrid protein-inorganic nanoparticles: From tumor-targeted drug delivery to cancer imaging. J. Control. Release 2016, 243, 303-322. [CrossRef] [PubMed]

3. Fan, W.; Yung, B.C.; Chen, X. Stimuli-responsive NO release for on-demand gas-sensitized synergistic cancer therapy. Angew. Chem. Int. Ed. 2018, 57, 8383-8394. [CrossRef] [PubMed]

4. Fang, R.H.; Jiang, Y.; Fang, J.C.; Zhang, L. Cell membrane-derived nanomaterials for biomedical applications. Biomaterials 2017, 128, 69-83. [CrossRef] [PubMed] 
5. Gao, M.; Yu, F.; Lv, C.; Choo, J.; Chen, L. Fluorescent chemical probes for accurate tumor diagnosis and targeting therapy. Chem. Soc. Rev. 2017, 46, 2237-2271. [CrossRef] [PubMed]

6. Gu, Z.; Zhu, S.; Yan, L.; Zhao, F.; Zhao, Y. Graphene-based smart platforms for combined cancer therapy. Adv. Mater. 2019, 31, 1800662. [CrossRef] [PubMed]

7. Guo, X.; You, J. Near infrared light-controlled therapeutic molecules release of nanocarriers in cancer therapy. J. Pharm. Investig. 2017, 47, 297-316. [CrossRef]

8. Hu, Y.; Mignani, S.; Majoral, J.P.; Shen, M.; Shi, X. Construction of iron oxide nanoparticle-based hybrid platforms for tumor imaging and therapy. Chem. Soc. Rev. 2018, 47, 1874-1900. [CrossRef]

9. Guan, Q.; Li, Y.A.; Li, W.Y.; Dong, Y.B. Photodynamic therapy based on nanoscale metal-organic frameworks: From material design to cancer nanotherapeutics. Chem. Asian J. 2018, 13, 3122-3149. [CrossRef]

10. Jeon, G.; Ko, Y.T. Enhanced photodyamic therapy via photosensitizer-loaded nanoparticles for cancer treatment. J. Pharm. Investig. 2019, 49, 1-8. [CrossRef]

11. Le, Q.V.; Choi, J.; Oh, Y.K. Nano delivery systems and cancer immunotherapy. J. Pharm. Investig. 2018, 48, 527-539. [CrossRef]

12. Lee, M.K. Clinical usefulness of liposomal formulations in cancer therapy: Lessons from the experiences of doxorubicin. J. Pharm. Investig. 2019, 49, 203-214. [CrossRef]

13. Liu, Y.; Bhattarai, P.; Dai, Z.; Chen, X. Photothermal therapy and photoacoustic imaging via nanotheranostics in fighting cancer. Chem. Soc. Rev. 2019, 48, 2053-2108. [CrossRef] [PubMed]

14. Raichur, V.; Devi, V.K. Formulation and evaluation of osteotropic drug delivery system of methotrexate with a potential for passive bone targeting. J. Pharm. Investig. 2017, 47, 335-347. [CrossRef]

15. Sobh, R.A.; Nasr, H.E.; Moustafa, A.B.; Mohamed, W.S. Tailoring of anticancer drugs loaded in MWCNT/Poly(MMA-co-HEMA) nanosphere composite by using in situ microemulsion polymerization. J. Pharm. Investig. 2019, 49, 45-55. [CrossRef]

16. Sun, Q.; Barz, M.; De Geest, B.G.; Diken, M.; Hennink, W.E.; Kiessling, F.; Lammers, T.; Shi, Y. Nanomedicine and macroscale materials in immuno-oncology. Chem. Soc. Rev. 2019, 48, 351-381. [CrossRef] [PubMed]

17. Tang, H.; Zheng, Y.; Chen, Y. Materials chemistry of nanoultrasonic biomedicine. Adv. Mater. 2017, 29, 1604105. [CrossRef] [PubMed]

18. Tang, W.L.; Tang, W.H.; Li, S.D. Cancer theranostic applications of lipid-based nanoparticles. Drug Discov. Today 2018, 23, 1159-1166. [CrossRef] [PubMed]

19. Wang, H.; Li, X.; Tse, B.W.; Yang, H.; Thorling, C.A.; Liu, Y.; Touraud, M.; Chouane, J.B.; Liu, X.; Roberts, M.S.; et al. Indocyanine green-incorporating nanoparticles for cancer theranostics. Theranostics 2018, 8, 1227-1242. [CrossRef]

20. Youn, Y.S.; Kwag, D.S.; Lee, E.S. Multifunctional nano-sized fullerenes for advanced tumor therapy. J. Pharm. Investig. 2017, 47, 1-10. [CrossRef]

21. Golombek, S.K.; May, J.N.; Theek, B.; Appold, L.; Drude, N.; Kiessling, F.; Lammers, T. Tumor targeting via EPR: Strategies to enhance patient responses. Adv. Drug Deliv. Rev. 2018, 130, 17-38. [CrossRef] [PubMed]

22. Maeda, H. Macromolecular therapeutics in cancer treatment: The EPR effect and beyond. J. Control. Release 2012, 164, 138-144. [CrossRef] [PubMed]

23. Maeda, H.; Wu, J.; Sawa, T.; Matsumura, Y.; Hori, K. Tumor vascular permeability and the EPR effect in macromolecular therapeutics: A review. J. Control. Release 2000, 65, 271-284. [CrossRef]

24. Nichols, J.W.; Bae, Y.H. EPR: Evidence and fallacy. J. Control. Release 2014, 190, 451-464. [CrossRef] [PubMed]

25. Maeda, H.; Nakamura, H.; Fang, J. The EPR effect for macromolecular drug delivery to solid tumors: Improvement of tumor uptake, lowering of systemic toxicity, and distinct tumor imaging in vivo. Adv. Drug Deliv. Rev. 2013, 65, 71-79. [CrossRef] [PubMed]

26. Fang, J.; Nakamura, H.; Maeda, H. The EPR effect: Unique features of tumor blood vessels for drug delivery, factors involved, and limitations and augmentation of the effect. Adv. Drug Deliv. Rev. 2011, 63, 136-151. [CrossRef] [PubMed]

27. Danhier, F.; Feron, O.; Préat, V. To exploit the tumor microenvironment: Passive and active tumor targeting of nanocarriers for anti-cancer drug delivery. J. Control. Release 2010, 148, 135-146. [CrossRef]

28. Jeong, J.Y.; Hong, E.H.; Lee, S.Y.; Lee, J.Y.; Song, J.H.; Ko, S.H.; Shim, J.S.; Choe, S.; Kim, D.D.; Ko, H.J.; et al. Boronic acid-tethered amphiphilic hyaluronic acid derivative-based nanoassemblies for tumor targeting and penetration. Acta Biomater. 2017, 53, 414-426. [CrossRef] 
29. Lee, J.Y.; Chung, S.J.; Cho, H.J.; Kim, D.D. Phenylboronic acid-decorated chondroitin sulfate A-based theranostic nanoparticles for enhanced tumor targeting and penetration. Adv. Funct. Mater. 2015, 25, 3705-3717. [CrossRef]

30. Lee, S.Y.; Cho, H.J. Amine-functionalized poly(lactic-co-glycolic acid) nanoparticles for improved cellular uptake and tumor penetration. Colloids Surf. B Biointerfaces 2016, 148, 85-94. [CrossRef]

31. Lee, S.Y.; Cho, H.J. Mitochondria targeting and destabilizing hyaluronic acid derivative-based nanoparticles for the delivery of lapatinib to triple-negative breast cancer. Biomacromolecules 2019, 20, 835-845. [CrossRef] [PubMed]

32. Lee, S.Y.; Ko, S.H.; Shim, J.S.; Kim, D.D.; Cho, H.J. Tumor targeting and lipid rafts disrupting hyaluronic acid-cyclodextrin-based nanoassembled structure for cancer therapy. ACS Appl. Mater. Interfaces 2018, 10, 36628-36640. [CrossRef] [PubMed]

33. Lee, S.Y.; Koo, J.S.; Yang, M.; Cho, H.J. Application of temporary agglomeration of chitosan-coated nanoparticles for the treatment of lung metastasis of melanoma. J. Colloid Interface Sci. 2019, 544, 266-275. [CrossRef] [PubMed]

34. Lee, S.Y.; Park, J.H.; Ko, S.H.; Shim, J.S.; Kim, D.D.; Cho, H.J. Mussel-inspired hyaluronic acid derivative nanostructures for improved tumor targeting and penetration. ACS Appl. Mater. Interfaces 2017, 9, 22308-22320. [CrossRef] [PubMed]

35. Li, C.; Zhang, Y.; Chen, G.; Hu, F.; Zhao, K.; Wang, Q. Engineered multifunctional nanomedicine for simultaneous stereotactic chemotherapy and inhibited osteolysis in an orthotopic model of bone metastasis. Adv. Mater. 2017, 29, 1605754. [CrossRef] [PubMed]

36. Sun, Q.; Ojha, T.; Kiessling, F.; Lammers, T.; Shi, Y. Enhancing tumor penetration of nanomedicines. Biomacromolecules 2017, 18, 1449-1459. [CrossRef] [PubMed]

37. Tian, B.; Li, J.; Pang, R.; Dai, S.; Li, T.; Weng, Y.; Jin, Y.; Hua, Y. Gold nanoparticles biosynthesized and functionalized using a hydroxylated tetraterpenoid trigger gene expression changes and apoptosis in cancer cells. ACS Appl. Mater. Interfaces 2018, 10, 37353-37363. [CrossRef] [PubMed]

38. Yang, J.; Li, L.; Kopeček, J. Biorecognition: A key to drug-free macromolecular therapeutics. Biomaterials 2019, 190-191, 11-23. [CrossRef] [PubMed]

39. Bhushan, B.; Khanadeev, V.; Khlebtsov, B.; Khlebtsov, N.; Gopinath, P. Impact of albumin based approaches in nanomedicine: Imaging, targeting and drug delivery. Adv. Colloid Interface Sci. 2017, 246, 13-39. [CrossRef]

40. De Matteis, V.; Cascione, M.; Toma, C.C.; Leporatti, S. Silver nanoparticles: Synthetic routes, in vitro toxicity and theranostic applications for cancer disease. Nanomaterials 2018, 8, 319. [CrossRef]

41. Dykman, L.A.; Khlebtsov, N.G. Multifunctional gold-based nanocomposites for theranostics. Biomaterials 2016, 108, 13-34. [CrossRef] [PubMed]

42. Hong, S.H.; Choi, Y. Mesoporous silica-based nanoplatforms for the delivery of photodynamic therapy agents. J. Pharm. Investig. 2018, 48, 3-17. [CrossRef] [PubMed]

43. Kim, H.S.; Lee, D.Y. Photothermal therapy with gold nanoparticles as an anticancer medication. J. Pharm. Investig. 2017, 47, 19-26. [CrossRef]

44. Kim, S.; Lee, S.Y.; Cho, H.J. Berberine and zinc oxide-based nanoparticles for the chemo-photothermal therapy of lung adenocarcinoma. Biochem. Biophys. Res. Commun. 2018, 501, 765-770. [CrossRef] [PubMed]

45. Koo, J.S.; Lee, S.Y.; Azad, M.O.K.; Kim, M.; Hwang, S.J.; Nam, S.; Kim, S.; Chae, B.J.; Kang, W.S.; Cho, H.J. Development of iron(II) sulfate nanoparticles produced by hot-melt extrusion and their therapeutic potentials for colon cancer. Int. J. Pharm. 2019, 558, 388-395. [CrossRef] [PubMed]

46. Lee, J.J.; Lee, S.Y.; Park, J.H.; Kim, D.D.; Cho, H.J. Cholesterol-modified poly(lactide-co-glycolide) nanoparticles for tumor-targeted drug delivery. Int. J. Pharm. 2016, 509, 483-491. [CrossRef] [PubMed]

47. Lee, J.S.; Youn, Y.H.; Kwon, I.K.; Ko, N.R. Recent advances in quantum dots for biomedical applications. J. Pharm. Investig. 2018, 48, 209-214. [CrossRef]

48. Lee, J.Y.; Chung, S.J.; Cho, H.J.; Kim, D.D. Iodinated hyaluronic acid oligomer-based nanoassemblies for tumor-targeted drug delivery and cancer imaging. Biomaterials 2016, 85, 218-231. [CrossRef]

49. Lee, J.Y.; Park, J.H.; Lee, J.J.; Lee, S.Y.; Chung, S.J.; Cho, H.J.; Kim, D.D. Polyethylene glycol-conjugated chondroitin sulfate A derivative nanoparticles for tumor-targeted delivery of anticancer drugs. Carbohydr. Polym. 2016, 151, 68-77. [CrossRef] 
50. Lee, J.Y.; Termsarasab, U.; Lee, M.Y.; Kim, D.H.; Lee, S.Y.; Kim, J.S.; Cho, H.J.; Kim, D.D. Chemosensitizing indomethacin-conjugated chitosan oligosaccharide nanoparticles for tumor-targeted drug delivery. Acta Biomater. 2017, 57, 262-273. [CrossRef]

51. Lee, J.Y.; Termsarasab, U.; Park, J.H.; Lee, S.Y.; Ko, S.H.; Shim, J.S.; Chung, S.J.; Cho, H.J.; Kim, D.D. Dual CD44 and folate receptor-targeted nanoparticles for cancer diagnosis and anticancer drug delivery. J. Control. Release 2016, 236, 38-46. [CrossRef] [PubMed]

52. Lee, S.Y.; Cho, H.J. An $\alpha$-tocopheryl succinate enzyme-based nanoassembly for cancer imaging and therapy. Drug Deliv. 2018, 25, 738-749. [CrossRef] [PubMed]

53. Oberli, M.A.; Reichmuth, A.M.; Dorkin, J.R.; Mitchell, M.J.; Fenton, O.S.; Jaklenec, A.; Anderson, D.G.; Langer, R.; Blankschtein, D. Lipid nanoparticle assisted mRNA delivery for potent cancer immunotherapy. Nano Lett. 2017, 17, 1326-1335. [CrossRef] [PubMed]

54. Park, J.H.; Cho, H.J.; Yoon, H.Y.; Yoon, I.S.; Ko, S.H.; Shim, J.S.; Cho, J.H.; Park, J.H.; Kim, K.; Kwon, I.C.; et al. Hyaluronic acid derivative-coated nanohybrid liposomes for cancer imaging and drug delivery. J. Control. Release 2014, 174, 98-108. [CrossRef] [PubMed]

55. Sarisozen, C.; Pan, J.; Dutta, I.; Torchilin, V.P. Polymers in the co-delivery of siRNA and anticancer drugs to treat multidrug-resistant tumors. J. Pharm. Investig. 2017, 47, 37-49. [CrossRef]

56. Sim, T.; Lim, C.; Hoang, N.H.; Oh, K.T. Recent advance of $\mathrm{pH}$-sensitive nanocarriers targeting solid tumors. J. Pharm. Investig. 2017, 47, 383-394. [CrossRef]

57. Tasciotti, E. Smart cancer therapy with DNA orgami. Nat. Biotechnol. 2018, 36, 234-235. [CrossRef]

58. Zhu, B.; Wang, L.; Li, J.; Fan, C. Precisely tailored DNA nanostructures and their theranostic applications. Chem. Rec. 2017, 17, 1213-1230. [CrossRef]

59. Martins, C.; Sousa, F.; Araújo, F.; Sarmento, B. Functionalizing PLGA and PLGA derivatives for drug delivery and tissue regeneration applications. Adv. Healthc. Mater. 2018, 7, 1701035. [CrossRef]

60. Swider, E.; Koshkina, O.; Tel, J.; Cruz, L.J.; de Vries, I.J.M.; Srinivas, M. Customizing poly(lactic-co-glycolic acid) particles for biomedical applications. Acta Biomater. 2018, 73, 38-51. [CrossRef]

61. Danhier, F.; Ansorena, E.; Silva, J.M.; Coco, R.; Le Breton, A.; Préat, V. PLGA-based nanoparticles: An overview of biomedical applications. J. Control. Release 2012, 161, 505-522. [CrossRef] [PubMed]

62. Mir, M.; Ahmed, N.; Rehman, A.U. Recent applications of PLGA based nanostructures in drug delivery. Colloids Surf. B Biointerfaces 2017, 159, 217-231. [CrossRef] [PubMed]

63. Chen, H.; Li, F.; Yao, Y.; Wang, Z.; Zhang, Z.; Tan, N. Redox dual-responsive and $\mathrm{O}_{2}$-evolving theranostic nanosystem for highly selective chemotherapy against hypoxic tumors. Theranostics 2019, 9, 90-103. [CrossRef] [PubMed]

64. Gao, M.; Liang, C.; Song, X.; Chen, Q.; Jin, Q.; Wang, C.; Liu, Z. Erythrocyte-membrane-enveloped perfluorocarbon as nanoscale artificial red blood cells to relieve tumor hypoxia and enhance cancer radiotherapy. Adv. Mater. 2017, 29, 1701429. [CrossRef] [PubMed]

65. Park, J.H.; Lee, J.Y.; Termsarasab, U.; Yoon, I.S.; Ko, S.H.; Shim, J.S.; Cho, H.J.; Kim, D.D. Development of poly(lactic-co-glycolic) acid nanoparticles-embedded hyaluronic acid-ceramide-based nanostructure for tumor-targeted drug delivery. Int. J. Pharm. 2014, 473, 426-433. [CrossRef] [PubMed]

66. Saneja, A.; Arora, D.; Kumar, R.; Dubey, R.D.; Panda, A.K.; Gupta, P.N. CD44 targeted PLGA nanomedicines for cancer chemotherapy. Eur. J. Pharm. Sci. 2018, 121, 47-58. [CrossRef] [PubMed]

67. Acharya, S.; Sahoo, S.K. PLGA nanoparticles containing various anticancer agents and tumour delivery by EPR effect. Adv. Drug Deliv. Rev. 2011, 63, 170-183. [CrossRef]

68. Ding, D.; Zhu, Q. Recent advances of PLGA micro/nanoparticles for the delivery of biomacromolecular therapeutics. Mater. Sci. Eng. C Mater. Biol. Appl. 2018, 92, 1041-1060. [CrossRef]

69. Lee, S.Y.; Cho, H.J. Dopamine-conjugated poly(lactic-co-glycolic acid) nanoparticles for protein delivery to macrophages. J. Colloid Interface Sci. 2017, 490, 391-400. [CrossRef]

70. Park, J.H.; Cho, H.J.; Kim, D.D. Poly((D,L)lactic-glycolic)acid-star glucose nanoparticles for glucose transporter and hypoglycemia-mediated tumor targeting. Int. J. Nanomed. 2017, 12, 7453-7467. [CrossRef]

71. Allahyari, M.; Mohit, E. Peptide/protein vaccine delivery system based on PLGA particles. Hum. Vaccin. Immunother. 2016, 12, 806-828. [CrossRef] [PubMed]

72. Rezvantalab, S.; Drude, N.I.; Moraveji, M.K.; Guvener, N.; Koons, E.K.; Shi, Y.; Lammers, T.; Kiessling, F. PLGA-based nanoparticles in cancer treatment. Front. Pharmacol. 2018, 9, 1260. [CrossRef] [PubMed] 
73. Dinarvand, R.; Sepehri, N.; Manoochehri, S.; Rouhani, H.; Atyabi, F. Polylactide-co-glycolide nanoparticles for controlled delivery of anticancer agents. Int. J. Nanomed. 2011, 6, 877-895. [CrossRef] [PubMed]

74. Booysen, L.L.; Kalombo, L.; Brooks, E.; Hansen, R.; Gilliland, J.; Gruppo, V.; Lungenhofer, P.; Semete-Makokotlela, B.; Swai, H.S.; Kotze, A.F.; et al. In vivo/in vitro pharmacokinetic and pharmacodynamic study of spray-dried poly-(DL-lactic-co-glycolic) acid nanoparticles encapsulating rifampicin and isoniazid. Int. J. Pharm. 2013, 444, 10-17. [CrossRef] [PubMed]

75. Kapoor, D.N.; Bhatia, A.; Kaur, R.; Sharma, R.; Kaur, G.; Dhawan, S. PLGA: A unique polymer for drug delivery. Ther. Deliv. 2015, 6, 41-58. [CrossRef] [PubMed]

76. Lee, J.Y.; Kim, J.S.; Cho, H.J.; Kim, D.D. Poly(styrene)-b-poly(DL-lactide) copolymer-based nanoparticles for anticancer drug delivery. Int. J. Nanomed. 2014, 9, 2803-2813.

77. Rafiei, P.; Haddadi, A. Docetaxel-loaded PLGA and PLGA-PEG nanoparticles for intravenous application: Pharmacokinetics and biodistribution profile. Int. J. Nanomed. 2017, 12, 935-947. [CrossRef] [PubMed]

78. Sanna, V.; Roggio, A.M.; Posadino, A.M.; Cossu, A.; Marceddu, S.; Mariani, A.; Alzari, V.; Uzzau, S.; Pintus, G.; Sechi, M. Novel docetaxel-loaded nanoparticles based on poly(lactide-co-caprolactone) and poly(lactide-co-glycolide-co-caprolactone) for prostate cancer treatment: Formulation, characterization, and cytotoxicity studies. Nanoscale Res. Lett. 2011, 6, 260. [CrossRef]

79. Ashjari, M.; Khoee, S.; Mahdavian, A.R.; Rahmatolahzadeh, R. Self-assembled nanomicelles using PLGA-PEG amphiphilic block copolymer for insulin delivery: A physicochemical investigation and determination of CMC values. J. Mater. Sci. Mater. Med. 2012, 23, 943-953. [CrossRef]

80. Chen, X.; Chen, J.; Li, B.; Yang, X.; Zeng, R.; Liu, Y.; Li, T.; Ho, R.J.Y.; Shao, J. PLGA-PEG-PLGA triblock copolymeric micelles as oral drug delivery system: In vitro drug release and in vivo pharmacokinetics assessment. J. Colloid Interface Sci. 2017, 490, 542-552. [CrossRef]

81. Cai, Q.; Wang, L.; Deng, G.; Liu, J.; Chen, Q.; Chen, Z. Systemic delivery to central nervous system by engineered PLGA nanoparticles. Am. J. Transl. Res. 2016, 8, 749-764. [PubMed]

82. Chung, Y.I.; Kim, J.C.; Kim, Y.H.; Tae, G.; Lee, S.Y.; Kim, K.; Kwon, I.C. The effect of surface functionalization of PLGA nanoparticles by heparin- or chitosan-conjugated Pluronic on tumor targeting. J. Control. Release 2010, 143, 374-382. [CrossRef] [PubMed]

83. Hwang, H.S.; Shin, H.; Na, K. Combination of photodynamic therapy (PDT) and anti-tumor immunity in cancer therapy. J. Pharm. Investig. 2018, 48, 143-151. [CrossRef] [PubMed]

84. Kydd, J.; Jadia, R.; Velpurisiva, P.; Gad, A.; Paliwal, S.; Rai, P. Targeting strategies for the combination treatment of cancer using drug delivery systems. Pharmaceutics 2017, 9, 46. [CrossRef] [PubMed]

85. Li, K.; Ding, D.; Huo, D.; Pu, K.Y.; Thao, N.N.P.; Hu, Y.; Li, Z.; Liu, B. Conjugated polymer based nanoparticles as dual-modal probes for targeted in vivo fluorescence and magnetic resonance imaging. Adv. Funct. Mater. 2012, 22, 3107-3115. [CrossRef]

86. Chen, J.; Wu, Q.; Luo, L.; Wang, Y.; Zhong, Y.; Dai, H.B.; Sun, D.; Luo, M.L.; Wu, W.; Wang, G.X. Dual tumor-targeted poly(lactic-co-glycolic acid)-polyethylene glycol-folic acid nanoparticles: A novel biodegradable nanocarrier for secure and efficient antitumor drug delivery. Int. J. Nanomed. 2017, 12, 5745-5760. [CrossRef] [PubMed]

87. Liu, X.J.; Li, L.; Liu, X.J.; Li, Y.; Zhao, C.Y.; Wang, R.Q.; Zhen, Y.S. Mithramycin-loaded mPEG-PLGA nanoparticles exert potent antitumor efficacy against pancreatic carcinoma. Int. J. Nanomed. 2017, 12, 5255-5269. [CrossRef] [PubMed]

88. Lu, B.; Lv, X.; Le, Y. Chitosan-modified PLGA nanoparticles for control-released drug delivery. Polymers 2019, 11, 304. [CrossRef] [PubMed]

89. Shah, N.; Chaudhari, K.; Dantuluri, P.; Murthy, R.S.; Das, S. Paclitaxel-loaded PLGA nanoparticles surface modified with transferrin and Pluronic ${ }^{\circledR}$ P85, an in vitro cell line and in vivo biodistribution studies on rat model. J. Drug Target. 2009, 17, 533-542. [CrossRef] [PubMed]

90. Wang, H.; Zhao, Y.; Wang, H.; Gong, J.; He, H.; Shin, M.C.; Yang, V.C.; Huang, Y. Low-molecular-weight protamine-modified PLGA nanoparticles for overcoming drug-resistant breast cancer. J. Control. Release 2014, 192, 47-56. [CrossRef]

91. Lin, W.J.; Lee, W.C. Polysaccharide-modified nanoparticles with intelligent CD44 receptor targeting ability for gene delivery. Int. J. Nanomed. 2018, 13, 3989-4002. [CrossRef] [PubMed] 
92. Mehdizadeh, M.; Rouhani, H.; Sepehri, N.; Varshochian, R.; Ghahremani, M.H.; Amini, M.; Gharghabi, M.; Ostad, S.N.; Atyabi, F.; Baharian, A.; et al. Biotin decorated PLGA nanoparticles containing SN-38 designed for cancer therapy. Artif. Cells Nanomed. Biotechnol. 2017, 45, 495-504. [CrossRef] [PubMed]

93. Bao, W.; Liu, R.; Wang, Y.; Wang, F.; Xia, G.; Zhang, H.; Li, X.; Yin, H.; Chen, B. PLGA-PLL-PEG-Tf-based targeted nanoparticles drug delivery system enhance antitumor efficacy via intrinsic apoptosis pathway. Int. J. Nanomed. 2015, 10, 557-566.

94. Venugopal, V.; Krishnan, S.; Palanimuthu, V.R.; Sankarankutty, S.; Kalaimani, J.K.; Karupiah, S.; Kit, N.S.; Hock, T.T. Anti-EGFR anchored paclitaxel loaded PLGA nanoparticles for the treatment of triple negative breast cancer. In-vitro and in-vivo anticancer activities. PLoS ONE 2018, 13, e0206109. [CrossRef] [PubMed]

95. Babu, A.; Amreddy, N.; Muralidharan, R.; Pathuri, G.; Gali, H.; Chen, A.; Zhao, Y.D.; Munshi, A.; Ramesh, R. Chemodrug delivery using integrin-targeted PLGA-chitosan nanoparticle for lung cancer therapy. Sci. Rep. 2017, 7, 14674. [CrossRef] [PubMed]

96. Ni, M.; Xiong, M.; Zhang, X.; Cai, G.; Chen, H.; Zeng, Q.; Yu, Z. Poly(lactic-co-glycolic acid) nanoparticles conjugated with CD133 aptamers for targeted salinomycin delivery to CD133+ osteosarcoma cancer stem cells. Int. J. Nanomed. 2015, 10, 2537-2554.

97. Foroozandeh, P.; Aziz, A.A. Insight into cellular uptake and intracellular trafficking of nanoparticles. Nanoscale Res. Lett. 2018, 13, 339. [CrossRef] [PubMed]

98. Kou, L.; Sun, J.; Zhai, Y.; He, Z. The endocytosis and intracellular fate of nanomedicines: Implication for rational design. Asian J. Pharm. Sci. 2013, 8, 1-10. [CrossRef]

99. Malinovskaya, Y.; Melnikov, P.; Baklaushev, V.; Gabashvili, A.; Osipova, N.; Mantrov, S.; Ermolenko, Y.; Maksimenko, O.; Gorshkova, M.; Balabanyan, V.; et al. Delivery of doxorubicin-loaded PLGA nanoparticles into U87 human glioblastoma cells. Int. J. Pharm. 2017, 524, 77-90. [CrossRef]

100. Sahay, G.; Alakhova, D.Y.; Kabanov, A.V. Endocytosis of nanomedicines. J. Control. Release 2010, 145, $182-195$. [CrossRef]

101. Trindade, I.C.; Pound-Lana, G.; Pereira, D.G.S.; de Oliveira, L.A.M.; Andrade, M.S.; Vilela, J.M.C.; Postacchini, B.B.; Mosqueira, V.C.F. Mechanisms of interaction of biodegradable polyester nanocapsules with non-phagocytic cells. Eur. J. Pharm. Sci. 2018, 124, 89-104. [CrossRef]

102. Alshaer, W.; Hillaireau, H.; Fattal, E. Aptamer-guided nanomedicines for anticancer drug delivery. Adv. Drug Deliv. Rev. 2018, 134, 122-137. [CrossRef] [PubMed]

103. Salatin, S.; Yari Khosroushahi, A. Overviews on the cellular uptake mechanism of polysaccharide colloidal nanoparticles. J. Cell. Mol. Med. 2017, 21, 1668-1686. [CrossRef] [PubMed]

104. Kim, C.H.; Lee, S.G.; Kang, M.J.; Lee, S.; Choi, Y.W. Surface modification of lipid-based nanocarriers for cancer cell-specific drug targeting. J. Pharm. Investig. 2017, 47, 203-227. [CrossRef]

105. Ghosh, D.; Peng, X.; Leal, J.; Mohanty, R.P. Peptides as drug delivery vehicles across biological barriers. J. Pharm. Investig. 2018, 48, 89-111. [CrossRef] [PubMed]

106. Kreuter, J. Drug delivery to the central nervous system by polymeric nanoparticles: What do we know? Adv. Drug Deliv. Rev. 2014, 71, 2-14. [CrossRef]

107. Zhang, Z.; Wang, X.; Li, B.; Hou, Y.; Yang, J.; Yi, L. Development of a novel morphological paclitaxel-loaded PLGA microspheres for effective cancer therapy: In vitro and in vivo evaluations. Drug Deliv. 2018, 25, 166-177. [CrossRef] [PubMed]

108. Wang, M.; Zhang, Y.; Feng, J.; Gu, T.; Dong, Q.; Yang, X.; Sun, Y.; Wu, Y.; Chen, Y.; Kong, W. Preparation, characterization, and in vitro and in vivo investigation of chitosan-coated poly (D,L-lactide-co-glycolide) nanoparticles for intestinal delivery of exendin-4. Int. J. Nanomed. 2013, 8, 1141-1154.

109. Alibolandi, M.; Ramezani, M.; Abnous, K.; Hadizadeh, F. AS1411 aptamer-decorated biodegradable polyethylene glycol-poly(lactic-co-glycolic acid) nanopolymersomes for the targeted delivery of gemcitabine to non-small cell lung cancer in vitro. J. Pharm. Sci. 2016, 105, 1741-1750. [CrossRef]

110. Wei, J.; Sun, J.; Liu, Y. Enhanced targeting of prostate cancer-initiation cells by salinomycin-encapsulated lipid-PLGA nanoparticles linked with CD44 antibodies. Oncol. Lett. 2019, 17, 4024-4033.

111. Kou, L.; Yao, Q.; Sivaprakasam, S.; Luo, Q.; Sun, Y.; Fu, Q.; He, Z.; Sun, J.; Ganapathy, V. Dual targeting of 1-carnitine-conjugated nanoparticles to OCTN2 and $\mathrm{ATB}^{0,+}$ to deliver chemotherapeutic agents for colon cancer therapy. Drug Deliv. 2017, 24, 1338-1349. [CrossRef] [PubMed] 
112. Li, L.; Di, X.; Wu, M.; Sun, Z.; Zhong, L.; Wang, Y.; Fu, Q.; Kan, Q.; Sun, J.; He, Z. Targeting tumor highly-expressed LAT1 transporter with amino acid-modified nanoparticles: Toward a novel active targeting strategy in breast cancer therapy. Nanomedicine 2017, 13, 987-998. [CrossRef]

113. Cespedes, A.; Perez, M.J.; Gomara, M.J.; Wandosell, F.; Haro, I. Atorvastatin in PLGA-PEG nanoparticles derivatized with the HIV-TAT peptide protects neuronal cultures in an oxygen-glucose deprivation (OGD) model. Am. J. Nanotechnol. Nanomed. 2018, 1, 55-63.

114. Choi, D.H.; Park, Y.S. Arginine-rich peptide coated PLGA nanoparticles enhance polymeric delivery of antisense $\mathrm{HIF}_{1 \alpha}$-oligonucleotide to fully differentiated stiff adipocytes. Toxicol. Environ. Health Sci. 2019, 11, 1-10. [CrossRef]

115. Nottelet, B.; Darcos, V.; Coudane, J. Aliphatic polyesters for medical imaging and theranostic applications. Eur. J. Pharm. Biopharm. 2015, 97, 350-370. [CrossRef]

116. Reul, R.; Tsapis, N.; Hillaireau, H.; Sancey, L.; Mura, S.; Recher, M.; Nicolas, J.; Coll, J.L.; Fattal, E. Near infrared labeling of PLGA for in vivo imaging of nanoparticles. Polym. Chem. 2012, 3, 694-702. [CrossRef]

117. Ratzinger, G.; Agrawal, P.; Körner, W.; Lonkai, J.; Sanders, H.M.; Terreno, E.; Wirth, M.; Strijkers, G.J.; Nicolay, K.; Gabor, F. Surface modification of PLGA nanospheres with Gd-DTPA and Gd-DOTA for high-relaxivity MRI contrast agents. Biomaterials 2010, 31, 8716-8723. [CrossRef] [PubMed]

118. Subramanian, S.; Pandey, U.; Gugulothu, D.; Patravale, V.; Samuel, G. Modification of PLGA nanoparticles for improved properties as a $99 \mathrm{mTc}$-labeled agent in sentinel lymph node detection. Cancer Biother. Radiopharm. 2013, 28, 598-606. [CrossRef]

119. Nomikou, N.; Curtis, K.; McEwan, C.; O’Hagan, B.M.G.; Callan, B.; Callan, J.F.; McHale, A.P. A versatile, stimulus-responsive nanoparticle-based platform for use in both sonodynamic and photodynamic cancer therapy. Acta Biomater. 2017, 49, 414-421. [CrossRef]

120. Sivakumar, B.; Aswathy, R.G.; Romero-Aburto, R.; Mitcham, T.; Mitchel, K.A.; Nagaoka, Y.; Bouchard, R.R.; Ajayan, P.M.; Maekawa, T.; Sakthikumar, D.N. Highly versatile SPION encapsulated PLGA nanoparticles as photothermal ablators of cancer cells and as multimodal imaging agents. Biomater. Sci. 2017, 5, 432-443. [CrossRef]

121. Li, Q.; Li, C.; Tong, W. Nile red loaded PLGA nanoparticles surface modified with Gd-DTPA for potential dual-modal imaging. J. Nanosci. Nanotechnol. 2016, 16, 5569-5576. [CrossRef] [PubMed]

122. Yang, C.; Vu-Quang, H.; Husum, D.M.U.; Tingskov, S.J.; Vinding, M.S.; Nielsen, T.; Song, P.; Nielsen, N.C.; Nørregaard, R.; Kjems, J. Theranostic poly(lactic-co-glycolic acid) nanoparticle for magnetic resonance/infrared fluorescence bimodal imaging and efficient siRNA delivery to macrophages and its evaluation in a kidney injury model. Nanomedicine 2017, 13, 2451-2462. [CrossRef] [PubMed]

123. Xing, L.; Shi, Q.; Zheng, K.; Shen, M.; Ma, J.; Li, F.; Liu, Y.; Lin, L.; Tu, W.; Duan, Y.; et al. Ultrasound-mediated microbubble destruction (UMMD) facilitates the delivery of CA19-9 targeted and paclitaxel loaded mPEG-PLGA-PLL nanoparticles in pancreatic cancer. Theranostics 2016, 6, 1573-1587. [CrossRef] [PubMed]

124. Zhang, X.; Li, X.; Hua, H.; Wang, A.; Liu, W.; Li, Y.; Fu, F.; Shi, Y.; Sun, K. Cyclic hexapeptide-conjugated nanoparticles enhance curcumin delivery to glioma tumor cells and tissue. Int. J. Nanomed. 2017, 12, 5717-5732. [CrossRef] [PubMed]

125. Vats, M.; Mishra, S.K.; Baghini, M.S.; Chauhan, D.S.; Srivastava, R.; De, A. Near infrared fluorescence imaging in nano-therapeutics and photo-thermal evaluation. Int. J. Mol. Sci. 2017, 18, 924. [CrossRef] [PubMed]

126. da Silva, C.L.; Del Ciampo, J.O.; Rossetti, F.C.; Bentley, M.V.; Pierre, M.B. Improved in vitro and in vivo cutaneous delivery of protoporphyrin IX from PLGA-based nanoparticles. Photochem. Photobiol. 2013, 89, 1176-1184. [CrossRef] [PubMed]

127. Shen, X.; Li, T.; Chen, Z.; Xie, X.; Zhang, H.; Feng, Y.; Li, S.; Qin, X.; Yang, H.; Wu, C.; et al. NIR-light-triggered anticancer strategy for dual-modality imaging-guided combination therapy via a bioinspired hybrid PLGA nanoplatform. Mol. Pharm. 2019, 16, 1367-1384. [CrossRef] [PubMed]

128. Huang, H.; Dong, Y.; Zhang, Y.; Ru, D.; Wu, Z.; Zhang, J.; Shen, M.; Duan, Y.; Sun, Y. GSH-sensitive Pt(IV) prodrug-loaded phase-transitional nanoparticles with a hybrid lipid-polymer shell for precise theranostics against ovarian cancer. Theranostics 2019, 9, 1047-1065. [CrossRef]

129. Guo, Y.; Wang, X.Y.; Chen, Y.L.; Liu, F.Q.; Tan, M.X.; Ao, M.; Yu, J.H.; Ran, H.T.; Wang, Z.X. A light-controllable specific drug delivery nanoplatform for targeted bimodal imaging-guided photothermal/chemo synergistic cancer therapy. Acta Biomater. 2018, 80, 308-326. [CrossRef] 
130. Hao, Y.; Zhang, B.; Zheng, C.; Ji, R.; Ren, X.; Guo, F.; Sun, S.; Shi, J.; Zhang, H.; Zhang, Z.; et al. The tumor-targeting core-shell structured DTX-loaded PLGA@Au nanoparticles for chemo-photothermal therapy and X-ray imaging. J. Control. Release 2015, 220, 545-555. [CrossRef]

131. Hahn, M.A.; Singh, A.K.; Sharma, P.; Brown, S.C.; Moudgil, B.M. Nanoparticles as contrast agents for in-vivo bioimaging: Current status and future perspectives. Anal. Bioanal. Chem. 2011, 399, 3-27. [CrossRef] [PubMed]

132. Sah, H.; Thoma, L.A.; Desu, H.R.; Sah, E.; Wood, G.C. Concepts and practices used to develop functional PLGA-based nanoparticulate systems. Int. J. Nanomed. 2013, 8, 747-765. [CrossRef] [PubMed]

133. Tang, H.; Guo, Y.; Peng, L.; Fang, H.; Wang, Z.; Zheng, Y.; Ran, H.; Chen, Y. In vivo targeted, responsive, and synergistic cancer nanotheranostics by magnetic resonance imaging-guided synergistic high-intensity focused ultrasound ablation and chemotherapy. ACS Appl. Mater. Interfaces 2018, 10, 15428-15441. [CrossRef] [PubMed]

134. Mosafer, J.; Abnous, K.; Tafaghodi, M.; Mokhtarzadeh, A.; Ramezani, M. In vitro and in vivo evaluation of anti-nucleolin-targeted magnetic PLGA nanoparticles loaded with doxorubicin as a theranostic agent for enhanced targeted cancer imaging and therapy. Eur. J. Pharm. Biopharm. 2017, 113, 60-74. [CrossRef] [PubMed]

135. Singh, Y.; Durga Rao Viswanadham, K.K.; Kumar Jajoriya, A.; Meher, J.G.; Raval, K.; Jaiswal, S.; Dewangan, J.; Bora, H.K.; Rath, S.K.; Lal, J.; et al. Click biotinylation of PLGA template for biotin receptor oriented delivery of doxorubicin hydrochloride in 4 T1 cell-induced breast cancer. Mol. Pharm. 2017, 14, 2749-2765. [CrossRef] [PubMed]

136. Cui, Y.; Zhang, M.; Zeng, F.; Jin, H.; Xu, Q.; Huang, Y. Dual-targeting magnetic PLGA nanoparticles for codelivery of paclitaxel and curcumin for brain tumor therapy. ACS Appl. Mater. Interfaces 2016, 8, 32159-32169. [CrossRef] [PubMed]

137. Chen, Y.L.; Liu, F.Q.; Guo, Y.; Cheng, J.; Yang, L.; Lu, M.; Li, P.; Xu, J.; Yu, T.; Wang, Z.G.; et al. PA/US dual-modality imaging to guide VEGFR-2 targeted photothermal therapy using ZnPc-/PFH-loaded polymeric nanoparticles. Biomater. Sci. 2018, 6, 2130-2143. [CrossRef] [PubMed]

138. Euhus, D.M.; Hudd, C.; Laregina, M.C.; Johnson, F.E. Tumor measurement in the nude mouse. J. Surg. Oncol. 1986, 31, 229-234. [CrossRef] [PubMed]

139. Tomayko, M.M.; Reynolds, C.P. Determination of subcutaneous tumor size in athymic (nude) mice. Cancer Chemother. Pharmacol. 1989, 24, 148-154. [CrossRef]

140. Guo, J.; Gao, X.; Su, L.; Xia, H.; Gu, G.; Pang, Z.; Jiang, X.; Yao, L.; Chen, J.; Chen, H. Aptamer-functionalized PEG-PLGA nanoparticles for enhanced anti-glioma drug delivery. Biomaterials 2011, 32, 8010-8020. [CrossRef] [PubMed]

141. Wohlfart, S.; Khalansky, A.S.; Gelperina, S.; Maksimenko, O.; Bernreuther, C.; Glatzel, M.; Kreuter, J. Efficient chemotherapy of rat glioblastoma using doxorubicin-loaded PLGA nanoparticles with different stabilizers. PLoS ONE 2011, 6, e19121. [CrossRef] [PubMed]

142. Cook, R.L.; Householder, K.T.; Chung, E.P.; Prakapenka, A.V.; DiPerna, D.M.; Sirianni, R.W. A critical evaluation of drug delivery from ligand modified nanoparticles: Confounding small molecule distribution and efficacy in the central nervous system. J. Control. Release 2015, 220, 89-97. [CrossRef] [PubMed]

143. Wu, J.; Deng, C.; Meng, F.; Zhang, J.; Sun, H.; Zhong, Z. Hyaluronic acid coated PLGA nanoparticulate docetaxel effectively targets and suppresses orthotopic human lung cancer. J. Control. Release 2017, 259, 76-82. [CrossRef] [PubMed]

144. Moreno, D.; Zalba, S.; Navarro, Í.; De Ilarduya, C.T.; Garrido, M.J. Pharmacodynamics of cisplatin-loaded PLGA nanoparticles administered to tumor-bearing mice. Eur. J. Pharm. Biopharm. 2010, 74, 265-274. [CrossRef] [PubMed]

145. Mattheolabakis, G.; Taoufik, E.; Haralambous, S.; Roberts, M.L.; Avgoustakis, K. In vivo investigation of tolerance and antitumor activity of cisplatin-loaded PLGA-mPEG nanoparticles. Eur. J. Pharm. Biopharm. 2009, 71, 190-195. [CrossRef] [PubMed]

146. Saneja, A.; Kumar, R.; Mintoo, M.J.; Dubey, R.D.; Sangwan, P.L.; Mondhe, D.M.; Panda, A.K.; Gupta, P.N. Gemcitabine and betulinic acid co-encapsulated PLGA-PEG polymer nanoparticles for improved efficacy of cancer chemotherapy. Mater. Sci. Eng. C 2019, 98, 764-771. [CrossRef] [PubMed] 
147. Song, X.; You, J.; Shao, H.; Yan, C. Effects of surface modification of $\mathrm{As}_{2} \mathrm{O}_{3}$-loaded PLGA nanoparticles on its anti-liver cancer ability: An in vitro and in vivo study. Colloids Surf. B Biointerfaces 2018, 169, $289-297$. [CrossRef] [PubMed]

148. Liang, C.; Yang, Y.; Ling, Y.; Huang, Y.; Li, T.; Li, X. Improved therapeutic effect of folate-decorated PLGA-PEG nanoparticles for endometrial carcinoma. Bioorg. Med. Chem. 2011, 19, 4057-4066. [CrossRef] [PubMed]

149. Kang, T.; Gao, X.; Hu, Q.; Jiang, D.; Feng, X.; Zhang, X.; Song, Q.; Yao, L.; Huang, M.; Jiang, X.; et al. iNGR-modified PEG-PLGA nanoparticles that recognize tumor vasculature and penetrate gliomas. Biomaterials 2014, 35, 4319-4332. [CrossRef] [PubMed]

150. Zhang, L.; Hao, W.; Xu, L.; Gao, Y.; Wang, X.; Zhu, D.; Chen, Z.; Zhang, X.; Chen, H.; Mei, L. A $\mathrm{pH}$-sensitive methenamine mandelate-loaded nanoparticle induces DNA damage and apoptosis of cancer cells. Acta Biomater. 2017, 62, 246-256. [CrossRef]

151. Deng, K.; Li, C.; Huang, S.; Xing, B.; Jin, D.; Zeng, Q.; Hou, Z.; Lin, J. Recent progress in near infrared light triggered photodynamic therapy. Small 2017, 13, 1702299. [CrossRef]

152. Li, T.; Yan, L. Functional polymer nanocarriers for photodynamic therapy. Pharmaceuticals 2018, 11, 133. [CrossRef] [PubMed]

153. Bœuf-Muraille, G.; Rigaux, G.; Callewaert, M.; Zambrano, N.; Van Gulick, L.; Roullin, V.G.; Terryn, C.; Andry, M.C.; Chuburu, F.; Dukic, S.; et al. Evaluation of mTHPC-loaded PLGA nanoparticles for in vitro photodynamic therapy on C6 glioma cell line. Photodiagn. Photodyn. Ther. 2019, 25, 448-455. [CrossRef] [PubMed]

154. Lin, X.; Yan, S.Z.; Qi, S.S.; Xu, Q.; Han, S.S.; Guo, L.Y.; Zhao, N.; Chen, S.L.; Yu, S.Q. Transferrin-modified nanoparticles for photodynamic therapy enhance the antitumor efficacy of hypocrellin A. Front. Pharmacol. 2017, 8, 815. [CrossRef] [PubMed]

155. Son, J.; Yang, S.M.; Yi, G.; Roh, Y.J.; Park, H.; Park, J.M.; Choi, M.G.; Koo, H. Folate-modified PLGA nanoparticles for tumor-targeted delivery of pheophorbide a in vivo. Biochem. Biophys. Res. Commun. 2018, 498, 523-528. [CrossRef] [PubMed]

156. Xin, Y.; Liu, T.; Yang, C. Development of PLGA-lipid nanoparticles with covalently conjugated indocyanine green as a versatile nanoplatform for tumor-targeted imaging and drug delivery. Int. J. Nanomed. 2016, 11, 5807-5821. [CrossRef]

157. Vivek, R.; Varukattu, N.; Chandrababu, R.; Alok, S.; Thondhi, P.; Alagarsamy, V.; Kannan, S. Multifunctional nanoparticles for trimodal photodynamic therapy-mediated photothermal and chemotherapeutic effects. Photodiagn. Photodyn. Ther. 2018, 23, 244-253. [CrossRef] [PubMed]

158. Wang, X.; Shi, L.; Tu, Q.; Wang, H.; Zhang, H.; Wang, P.; Zhang, L.; Huang, Z.; Zhao, F.; Luan, H.; et al. Treating cutaneous squamous cell carcinoma using 5 -aminolevulinic acid polylactic-co-glycolic acid nanoparticle-mediated photodynamic therapy in a mouse model. Int. J. Nanomed. 2015, 10, 347-355.

159. Peng, Y.; Nie, J.; Cheng, W.; Liu, G.; Zhu, D.; Zhang, L.; Liang, C.; Mei, L.; Huang, L.; Zeng, X. A multifunctional nanoplatform for cancer chemo-photothermal synergistic therapy and overcoming multidrug resistance. Biomater. Sci. 2018, 6, 1084-1098. [CrossRef] [PubMed]

160. Nguyen, H.T.; Dai Phung, C.; Thapa, R.K.; Pham, T.T.; Tran, T.H.; Jeong, J.-H.; Ku, S.K.; Choi, H.-G.; Yong, C.S.; $\mathrm{Kim}$, J.O. Multifunctional nanoparticles as somatostatin receptor-targeting delivery system of polyaniline and methotrexate for combined chemo-photothermal therapy. Acta Biomater. 2018, 68, 154-167. [CrossRef] [PubMed]

161. Senthilkumar, M.; Mishra, P.; Jain, N.K. Long circulating PEGylated poly(D,L-lactide-co-glycolide) nanoparticulate delivery of Docetaxel to solid tumors. J. Drug Target. 2008, 16, 424-435. [CrossRef] [PubMed]

162. Moghimi, S.M.; Muir, I.S.; Illum, L.; Davis, S.S.; Kolb-Bachofen, V. Coating particles with a block co-polymer (poloxamine-908) suppresses opsonization but permits the activity of dysopsonins in the serum. Biochim. Biophys. Acta 1993, 1179, 157-165. [CrossRef]

163. Milane, L.; Duan, Z.F.; Amiji, M. Pharmacokinetics and biodistribution of lonidamine/paclitaxel loaded, EGFR-targeted nanoparticles in an orthotopic animal model of multi-drug resistant breast cancer. Nanomedicine 2011, 7, 435-444. [CrossRef]

164. Dhar, S.; Kolishetti, N.; Lippard, S.J.; Farokhzad, O.C. Targeted delivery of a cisplatin prodrug for safer and more effective prostate cancer therapy in vivo. Proc. Natl. Acad. Sci. USA 2011, 108, 1850-1855. [CrossRef] 
165. Avgoustakis, K.; Beletsi, A.; Panagi, Z.; Klepetsanis, P.; Karydas, A.G.; Ithakissios, D.S. PLGA-mPEG nanoparticles of cisplatin: In vitro nanoparticle degradation, in vitro drug release and in vivo drug residence in blood properties. J. Control. Release 2002, 79, 123-135. [CrossRef]

166. Ma, Y.; Sadoqi, M.; Shao, J. Biodistribution of indocyanine green-loaded nanoparticles with surface modifications of PEG and folic acid. Int. J. Pharm. 2012, 436, 25-31. [CrossRef]

167. Yin, P.; Wang, Y.; Qiu, Y.; Hou, L.; Liu, X.; Qin, J.; Duan, Y.; Liu, P.; Qiu, M.; Li, Q. Bufalin-loaded mPEG-PLGA-PLL-cRGD nanoparticles: Preparation, cellular uptake, tissue distribution, and anticancer activity. Int. J. Nanomed. 2012, 7, 3961-3969. [CrossRef]

168. Huang, J.; Zhang, H.; Yu, Y.; Chen, Y.; Wang, D.; Zhang, G.; Zhou, G.; Liu, J.; Sun, Z.; Sun, D.; et al. Biodegradable self-assembled nanoparticles of poly(D,L-lactide-co-glycolide)/hyaluronic acid block copolymers for target delivery of docetaxel to breast cancer. Biomaterials 2014, 35, 550-566. [CrossRef]

169. Chen, Z.; Tai, Z.; Gu, F.; Hu, C.; Zhu, Q.; Gao, S. Aptamer-mediated delivery of docetaxel to prostate cancer through polymeric nanoparticles for enhancement of antitumor efficacy. Eur. J. Pharm. Biopharm. 2016, 107, 130-141. [CrossRef]

170. Choi, S.J.; Choy, J.H. Layered double hydroxide nanoparticles as target-specific delivery carriers: Uptake mechanism and toxicity. Nanomedicine 2011, 6, 803-814. [CrossRef]

171. Jin, H.; Pi, J.; Zhao, Y.; Jiang, J.; Li, T.; Zeng, X.; Yang, P.; Evans, C.E.; Cai, J. EGFR-targeting PLGA-PEG nanoparticles as a curcumin delivery system for breast cancer therapy. Nanoscale 2017, 9, 16365-16374. [CrossRef] [PubMed]

172. Paolini, M.; Poul, L.; Berjaud, C.; Germain, M.; Darmon, A.; Bergere, M.; Pottier, A.; Levy, L.; Vibert, E. Nano-sized cytochrome P450 3A4 inhibitors to block hepatic metabolism of docetaxel. Int. J. Nanomed. 2017, 12, 5537-5556. [CrossRef] [PubMed]

173. Ahmad, N.; Alam, M.A.; Ahmad, R.; Naqvi, A.A.; Ahmad, F.J. Preparation and characterization of surface-modified PLGA-polymeric nanoparticles used to target treatment of intestinal cancer. Artif. Cells Nanomed. Biotechnol. 2018, 46, 432-446. [CrossRef] [PubMed]

174. Sharma, S.; Parmar, A.; Kori, S.; Sandhir, R. PLGA-based nanoparticles: A new paradigm in biomedical applications. Trends Anal. Chem. 2016, 80, 30-40. [CrossRef]

175. Navarro, S.M.; Morgan, T.W.; Astete, C.E.; Stout, R.W.; Coulon, D.; Mottram, P.; Sabliov, C.M. Biodistribution and toxicity of orally administered poly(lactic-co-glycolic) acid nanoparticles to F344 rats for 21 days. Nanomedicine 2016, 11, 1653-1669. [CrossRef] [PubMed] 